\title{
Mechanochemistry of supramolecules
}

\author{
Anima Bose and Prasenjit Mal
}

\author{
Review \\ Address: \\ School of Chemical Sciences, National Institute of Science Education \\ and Research (NISER), HBNI, Bhubaneswar, PO Bhimpur-Padanpur, \\ Via Jatni, District Khurda, Odisha 752050, India \\ Email: \\ Prasenjit Mal - pmal@niser.ac.in \\ ${ }^{*}$ Corresponding author \\ Keywords: \\ ball milling; mechanochemistry; self-assembly; solvent-free; \\ supramolecular
}

Beilstein J. Org. Chem. 2019, 15, 881-900.

doi:10.3762/bjoc. 15.86

Received: 19 January 2019

Accepted: 22 March 2019

Published: 12 April 2019

This article is part of the thematic issue "Mechanochemistry II".

Guest Editor: J. G. Hernández

(C) 2019 Bose and Mal; licensee Beilstein-Institut. License and terms: see end of document.

\begin{abstract}
The urge to use alternative energy sources has gained significant attention in the eye of chemists in recent years. Solution-based traditional syntheses are extremely useful, although they are often associated with certain disadvantages like generation of waste as by-products, use of large quantities of solvents which causes environmental hazard, etc. Contrastingly, achieving syntheses through mechanochemical methods are generally time-saving, environmentally friendly and more economical. This review is written to shed some light on supramolecular chemistry and the synthesis of various supramolecules through mechanochemistry.
\end{abstract}

\section{Introduction}

In living systems an important aspect is to create complex functional molecules from simpler units by following biomolecular mechanisms [1]. The biological assemblies for living beings are developed from processes of spontaneous self-assembly with a high degree of compartmentalization [2]. In addition, the same building units are often used across an enormous number of structures in a reversible fashion through thermodynamic control [3]. Conversely, small-molecule synthesis is generally performed under kinetically controlled reaction conditions through covalent approaches. By using common synthetic methodologies chemists are able to proficiently synthesize a variety of both natural and unnatural molecular scaffolds [4-6].

The era of supramolecular chemistry began with the introduction of coordination theory by Alfred Werner in 1893 [7] fol- lowed by the lock-and-key concept of Emil Fischer in 1894 [8]. Weak or non-covalent interactions had been used systematically in the early 1960 s by Lehn, Cram and Pederson to create targeted supramolecular architectures [9]. Small molecules, anions or cations could be assembled spontaneously to form supramolecular structures through self-assembly processes by exploiting the weak or non-covalent interactions [10]. Selfassembly is a kinetically reversible process which is more efficient than traditional stepwise synthesis concerning large molecules. Some recent developments in supramolecular chemistry are dynamic combinatorial chemistry [11], subcomponent selfassembly approach [12-14], and systems chemistry [15-18], etc.

There also has been growing interest towards exploration of nontraditional energy sources like visible light [19,20], micro- 
wave [21], mechanochemical mixing [22,23], ultrasound [24], etc. as alternative energy sources to replace common laboratory techniques [25]. Among them, especially mechanochemical synthesis [26-29] has gained popularity due to its advantage over conventional solution-based methods [30]. The process is highly beneficial as the solvent-free condition may make traditional workup superfluous [31,32]. Also, mechanochemical methods have high impact in ecology and economy as they save time [33]. Mechanochemical syntheses benefit from high to quantitative conversions, minimized steps for purification and diminished liberation of undesired byproducts [34,35]. In literature, classical small organic molecules' synthesis has been well explored which includes multistep synthesis [36-39]. However, the concept of supramolecular chemistry under mechanomilling conditions only has limited number of examples [4042].

\section{Review}

\section{Self-assembly}

During a metal-directed self-assembly process, the coordination geometry and coordination number at the metal center plays a central role in creating a self-assembled system. In 1962, Busch and coworker first demonstrated the concept of the template effect by choosing a suitable metal ion to control a self-assembly process $[43,44]$. The template enforces the assembly of the smaller units around it in a distinct and organized way favoring the formation of a particular product from a mixture with multiple possibilities [45]. Therefore, the concept of selection of appropriate metal ion(s) and ligand(s) has been demonstrated in various reports [46-49]. In Figure 1, a comprehensive framework is shown in which nanoscale architectures are built from various monodentate (pyridine; Figure 1a), bidentate (bipyridine, phenanthroline; Figure 1b) and tridentate (terpyridines; Figure 1c) ligands [49]. The model systems depicted in Figure 1 are constructed using metals like Pd(II) or $\mathrm{Pt}(\mathrm{II})$ ions for square planar geometry, $\mathrm{Cu}(\mathrm{I})$ or $\mathrm{Ag}(\mathrm{I})$ ions for tetrahedral geometry and $\mathrm{Co}(\mathrm{II}) / \mathrm{Cu}(\mathrm{II}) / \mathrm{Fe}(\mathrm{II}) / \mathrm{Zn}$ (II) $/ \mathrm{Hg}$ (II) for octahedral organization [50].

In Figure 2, Busch's first example of a metal-directed selfassembly is shown [44]. The mixing of diacetyl and 2-aminoethanethiol led to a dynamic mixture of products including $\mathbf{1}$. The square-planar directing metal ion nickel(II) induces the formation of cyclic product $\mathbf{2}$ through a process called self-sorting [51-53]. Subsequently, compound 2 underwent substitution with $\alpha, \alpha$ 'dibromo-o-xylene to create the nickel(II) complex 3 [54].

In 2014, James and co-workers reported a one-pot two-step mechanochemical synthesis of metal complexes 7 (Figure 3). First, the salen-type ligand $\mathbf{6}$ was synthesized from $o$-hydroxybenzaldehyde (4) and ethylenediamine (5). Subsequently, to the same pot appropriate metals were added to obtain the respective complexes 7 [55].

In 2002, Otera and co-workers reported the formation of some supramolecular self-assembled structures which was found to a)<smiles></smiles>

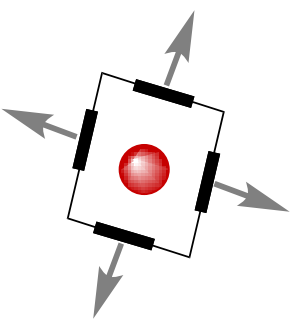

square plana coordination

$\mathrm{Q}=\operatorname{Pt}(\mathrm{II})$ or $\mathrm{Pd}(\mathrm{II})$ b)
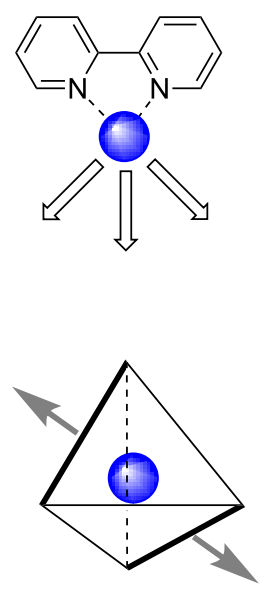

tetrahedral coordination c)

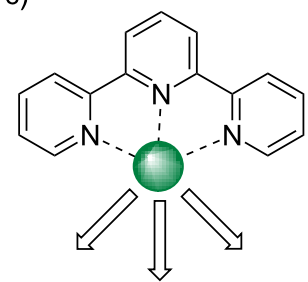

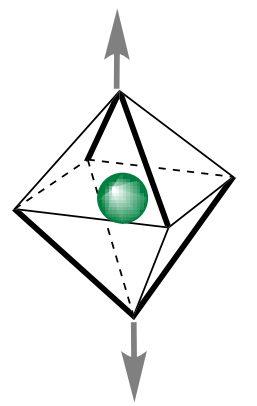

octahedral coordination 

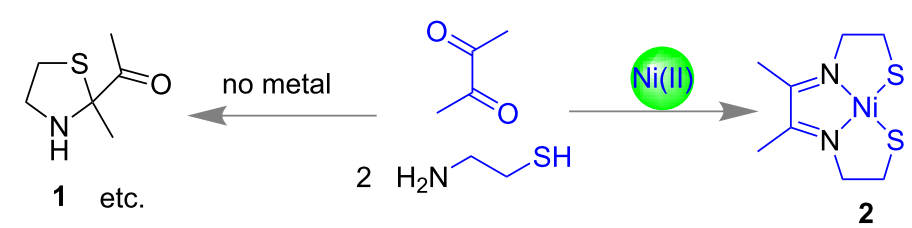

self-sorting<smiles>BrCc1ccccc1CBr</smiles>

substitution

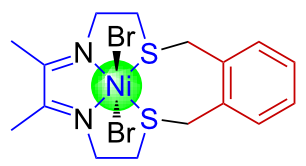

3

Figure 2: Examples of self-assembly or self-sorting and subsequent substitution.

2<smiles>O=Cc1ccccc1O</smiles><smiles>NCCN</smiles>

5

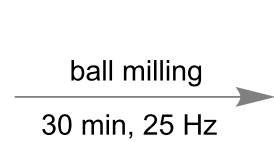

$30 \min , 25 \mathrm{~Hz}$

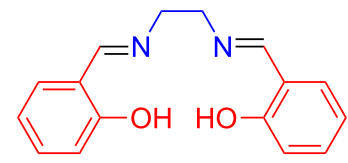

6 $(\mathrm{MeOH})$ $30 \mathrm{~min}, 25 \mathrm{~Hz}$

$\sqrt{1}$

$\mathrm{M} \equiv \mathrm{Cu}, \mathrm{Ni}, \mathrm{Zn}$

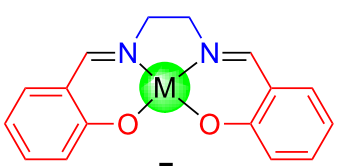

Figure 3: Synthesis of salen-type ligand followed by metal-complex formation in the same pot [55]

be faster under solvent-free mechanochemical condition than in aqueous media [56]. When a 1:1 mixture of the platinum salt $\left.\left[(\mathrm{en}) \mathrm{PtNO}_{3}\right)_{2}\right]$ and 4,4'-bipyridine were grinded in a mortar and pestle for $10 \mathrm{~min}$, an NMR yield of $76 \%$ was found for the formation of molecular square 8 (Figure $4 \mathrm{a}$ ). Similar structures were reported by Fujita's group [57] in which the formation of a Pt-based supramolecular square took more than four weeks at $100{ }^{\circ} \mathrm{C}$. Using a similar approach, Otera's group also demonstrated for the formation of a bowl-shaped assembly 9 in $90 \%$ yield upon grinding for $10 \mathrm{~min}$ 2,4,6-tri(pyridin-3-yl)-1,3,5triazine and palladium ((en) $\mathrm{Pd}\left(\mathrm{NO}_{3}\right)_{2}$, Figure $\left.4 \mathrm{~b}\right)$. Contrastingly, in solution the same synthesis took $4 \mathrm{~h}$ at $70{ }^{\circ} \mathrm{C}$ to isolate complex 9 in 56\% yield.

Ćurić and co-workers prepared cyclopalladated complexes such as $\mathbf{1 0}$ by a grinding method and were the first to confirm a mechanochemical $\mathrm{C}-\mathrm{H}$ bond activation of an unsymmetrically substituted azobenzene [58]. The cyclopalladation process was proved to be a highly regioselective process and the observed palladation rate was faster compared to the conventional solution-phase method. An equimolar amount of 4'-( $N, N$-dimethylamino)-4-nitroazobenzene and $\mathrm{Pd}(\mathrm{OAc})_{2}$ in the presence of $25 \mu \mathrm{L}$ of glacial acetic acid (for liquid-assisted grinding, LAG) led to the regioselective $\mathrm{C}-\mathrm{H}$ activation (Figure 5) [58].

In 2008, the mechanochemical synthesis of both [2]- and [4]rotaxanes was reported by Chiu and co-workers. The reactions led to high yields of the products $\mathbf{1 2}$ and $\mathbf{1 3}$ under solventfree conditions at a milling frequency of $22.5 \mathrm{~Hz}$ (Figure 6b) [59]. The stoppers were constructed in situ with 1,8-diaminonaphthalene through the formation of an imine via dehydration of the amine and aldehyde. 
a)

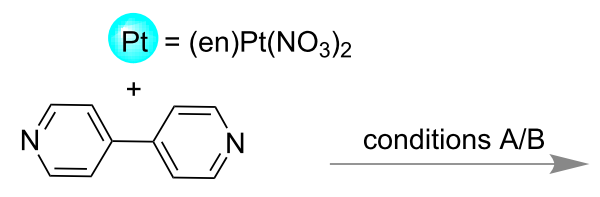

$A=D_{2} \mathrm{O}$ at $100{ }^{\circ} \mathrm{C}, 4$ weeks $(80 \%)$

$\mathrm{B}=$ solvent-free grinding, $10 \mathrm{~min}(76 \%)$
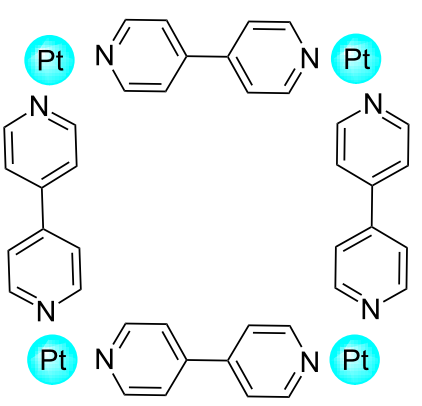

8

b)
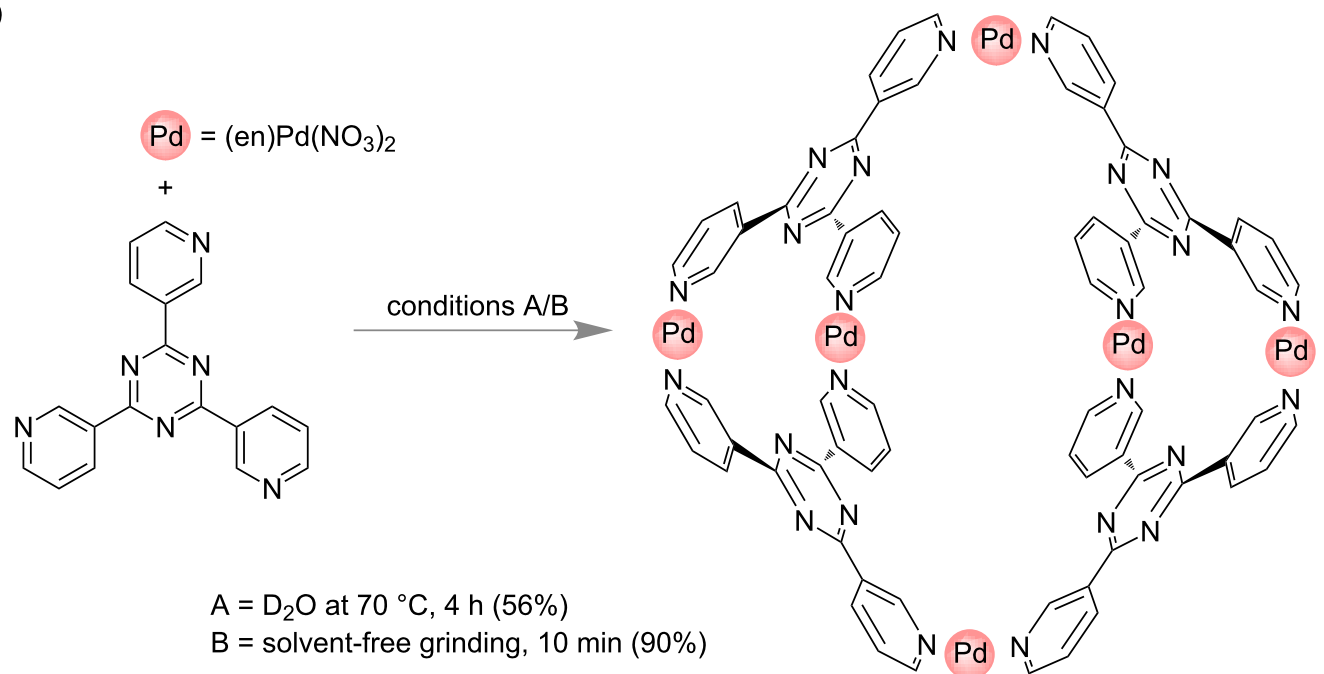

$A=D_{2} \mathrm{O}$ at $70^{\circ} \mathrm{C}, 4 \mathrm{~h}(56 \%)$

$\mathrm{B}=$ solvent-free grinding, $10 \mathrm{~min}(90 \%)$

9

Figure 4: Otera's solvent-free approach by which the formation of self-assembled supramolecules could be accelerated [56].

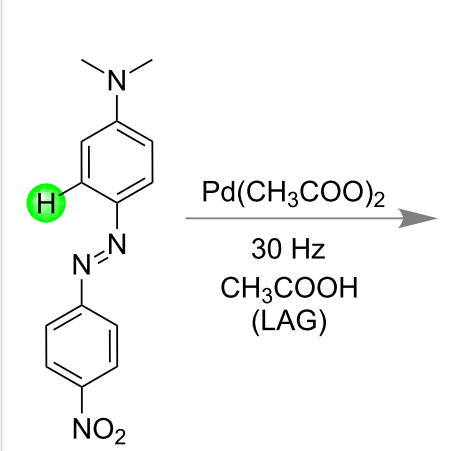<smiles></smiles>
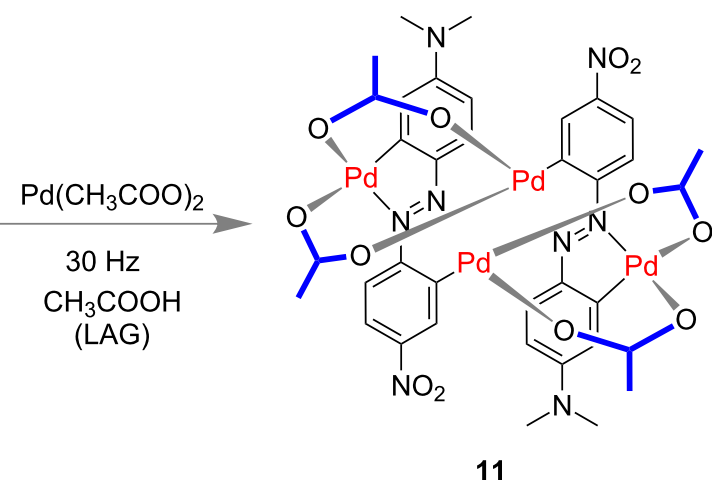

11

Figure 5: Synthesis of a Pd-based metalla-supramolecular assembly through mechanochemical activation for $\mathrm{C}-\mathrm{H}$-bond activation of unsymmetrically substituted azobenzene [58].

Interestingly, a synthesis of the smallest [2] rotaxane also has been demonstrated by the same group [60]. They applied a Diels-Alder reaction of 1,2,4,5-tetrazine with a terminal alkyne unit in a 21-crown-7-based [2]pseudorotaxane 14. The [2] rotaxane 15 was produced in $81 \%$ yield having pyridazine groups as stoppers (Figure 7). 
a)

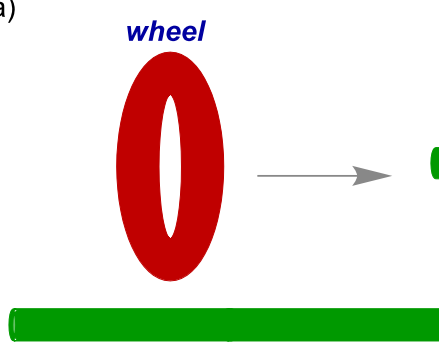

axel

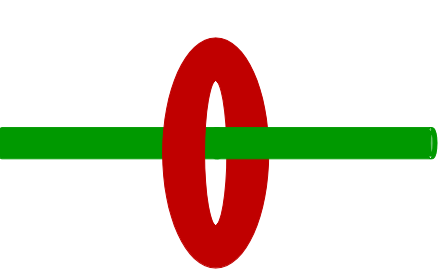

pseudorotaxane

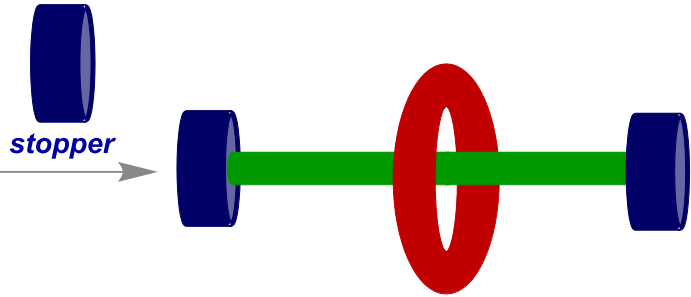

rotaxane

b)<smiles>O=Cc1ccc(C=[NH+]Cc2ccc(C=O)cc2)cc1</smiles><smiles>Nc1cccc2cccc(N)c12</smiles><smiles>[R]C(C)(C)C</smiles><smiles></smiles>

$1 \mathrm{~h}$

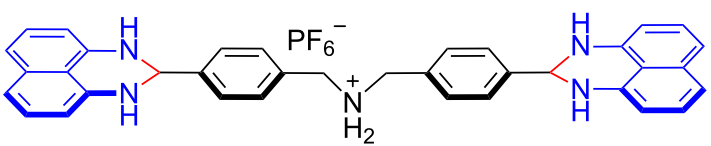

$13,44 \%$

Figure 6: a) Schematic representation for the construction of a [2]rotaxane. b) Chiu's ball-milling approach for the synthesis of [2]rotaxanes.

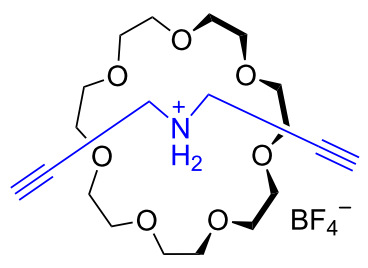

14

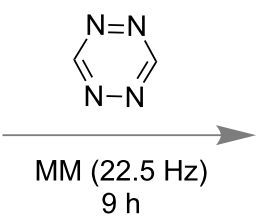

$9 \mathrm{~h}$

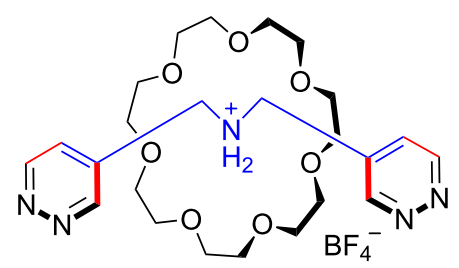

$15,81 \%$

Figure 7: Mechanochemical synthesis of the smallest [2]rotaxane.

Very recently, Nierengarten and co-workers reported a solventfree mechanochemical synthesis of pillar[5]arene-containing [2]rotaxanes (Figure 8). Mixing a 2:1 ratio of pillar[5]arene (wheel) with dodecanedioyl dichloride (axle) in $\mathrm{CHCl}_{3}$ resulted in the formation of pseudorotaxane $\mathbf{1 6}$ which was further treated with different amines (stopper) in a stainless-steel jar with 4 steel balls under milling conditions $(30 \mathrm{~Hz}$ for $1-2 \mathrm{~h}$ ). When for example, $N$-methyl-1,1,-diphenylmethanamine was used as one of the stoppers, diamido [2] rotaxane $\mathbf{1 7}$ was obtained with high yield (ca. 87\%) [61] (Figure 8).
In 2017, Wang and co-workers reported an efficient method for the synthesis of neutral donor-acceptor [2] rotaxanes such as $\mathbf{1 9}$ through liquid-assisted mechanochemical milling (Figure 9). The donor-acceptor interaction between the electron-deficient naphthalene diimide moiety and the electron-rich naphthalene moieties embedded in the macrocyclic polyethers played the vital role for the construction of the rotaxane system via pseudorotaxane 18. A shorter reaction time, use of small amounts of solvent and the high yield were the advantages over the solvent-mediated synthesis [62]. 


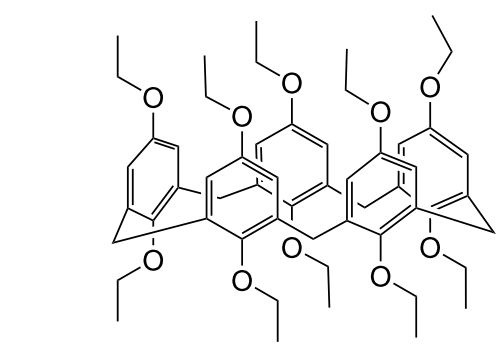

1,4-dimethoxypillar[5]arene as wheel

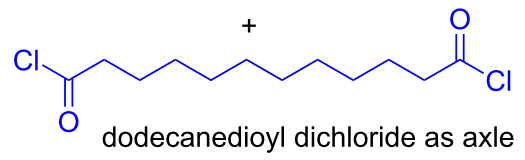
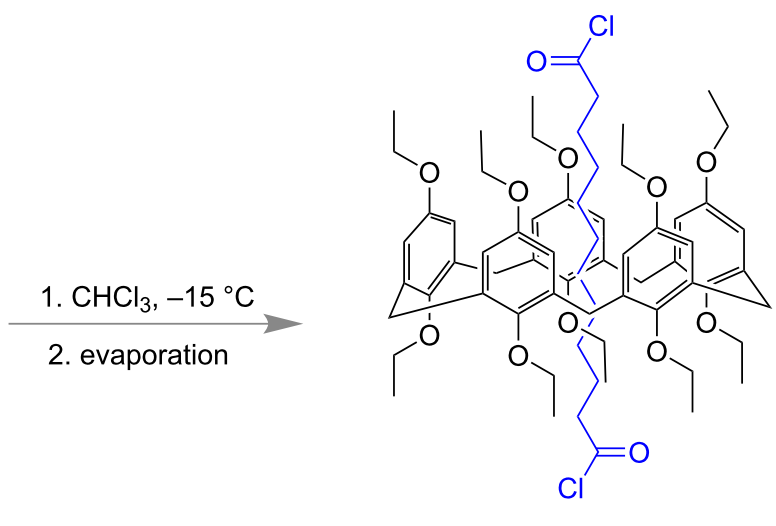

[2]pseudorotaxane (16)

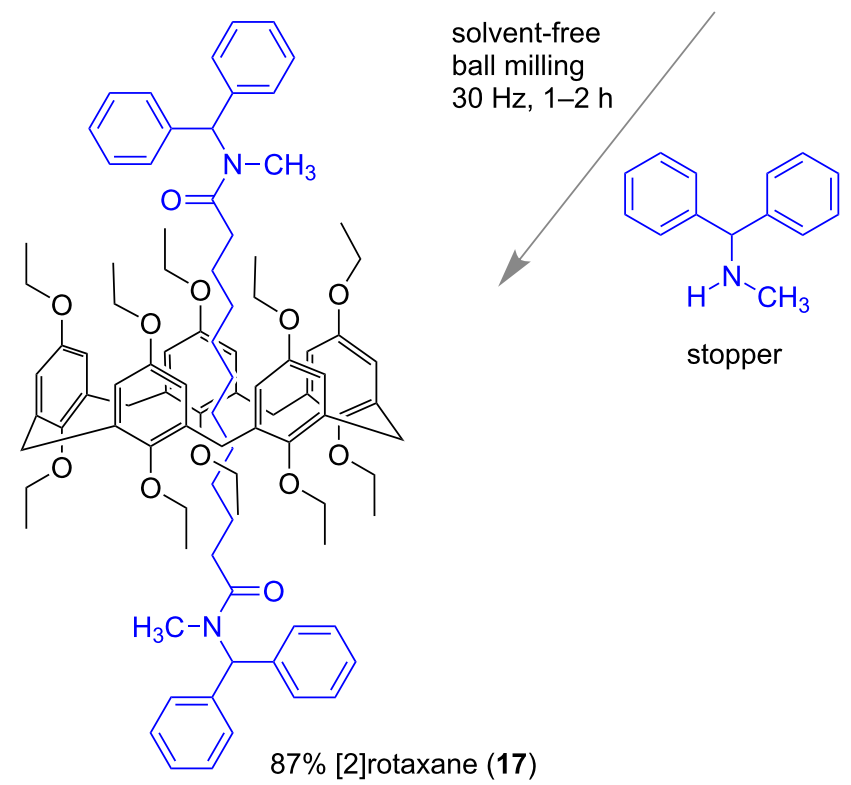

Figure 8: Solvent-free mechanochemical synthesis of pillar[5]arene-containing [2]rotaxanes [61].

\section{Macrocycle synthesis}

The mechanochemical synthesis of sphere-like nanostructures was reported by Severin and co-workers (Figure 10). Under ball-milling conditions $(20 \mathrm{~Hz})$, the condensation of 4-formylphenylboronic acid, pentaerythritol and 1,3,5-tri(aminomethyl)2,4,6-triethylbenzene afforded $94 \%$ of sphere-like compound 21 in $1 \mathrm{~h}$ [63].

In 2018, Wang and co-workers also demonstrated the synthesis of boronic ester cages under high-speed vibration milling (HSVM) conditions. The condensation of pentaerythritol and triboronic acid at $58 \mathrm{~Hz}$ for $40 \mathrm{~min}$ led to the formation of cage structure 22 (Figure 11) with nearly 96\% yield [64]. The authors also reported that the cage compounds such as $\mathbf{2 2}$ had high thermal stabilities by exhibiting a decomposition temperature up to $320^{\circ} \mathrm{C}$.
In 2013, Severin and co-workers reported the mechanochemical synthesis of large macrocycles with borasiloxane and imine links using a ball mill (Figure 12). In a polycondensation reaction using diamines, 4-formylbenzeneboronic acid and $t$ - $\mathrm{Bu}_{2} \mathrm{Si}(\mathrm{OH})_{2}$, borasiloxane-based macrocycle $\mathbf{2 3}$ was obtained in $>90 \%$ yield after $2 \times 45 \mathrm{~min}$ of grinding [65].

In 2017, Xu and his group developed the first method towards the synthesis of 2-dimensional aromatic polyamides (2DAPAs) under solvent-free ball-milling conditions [66]. Reacting 1,3,5benzenetricarbonyl chloride and 1,4-phenylenediamine in a ball mill afforded $75 \%$ of the desired $2 \mathrm{D}$ polymer 24 within $15 \mathrm{~min}$ (Figure 13). When using 4,4'-diaminobiphenyl in place of 1,4phenylenediamine the analogous $2 \mathrm{D}$ structure comprising biphenylene units was obtained within the same time albeit with a lower yield ( $\approx 65 \%)$. 


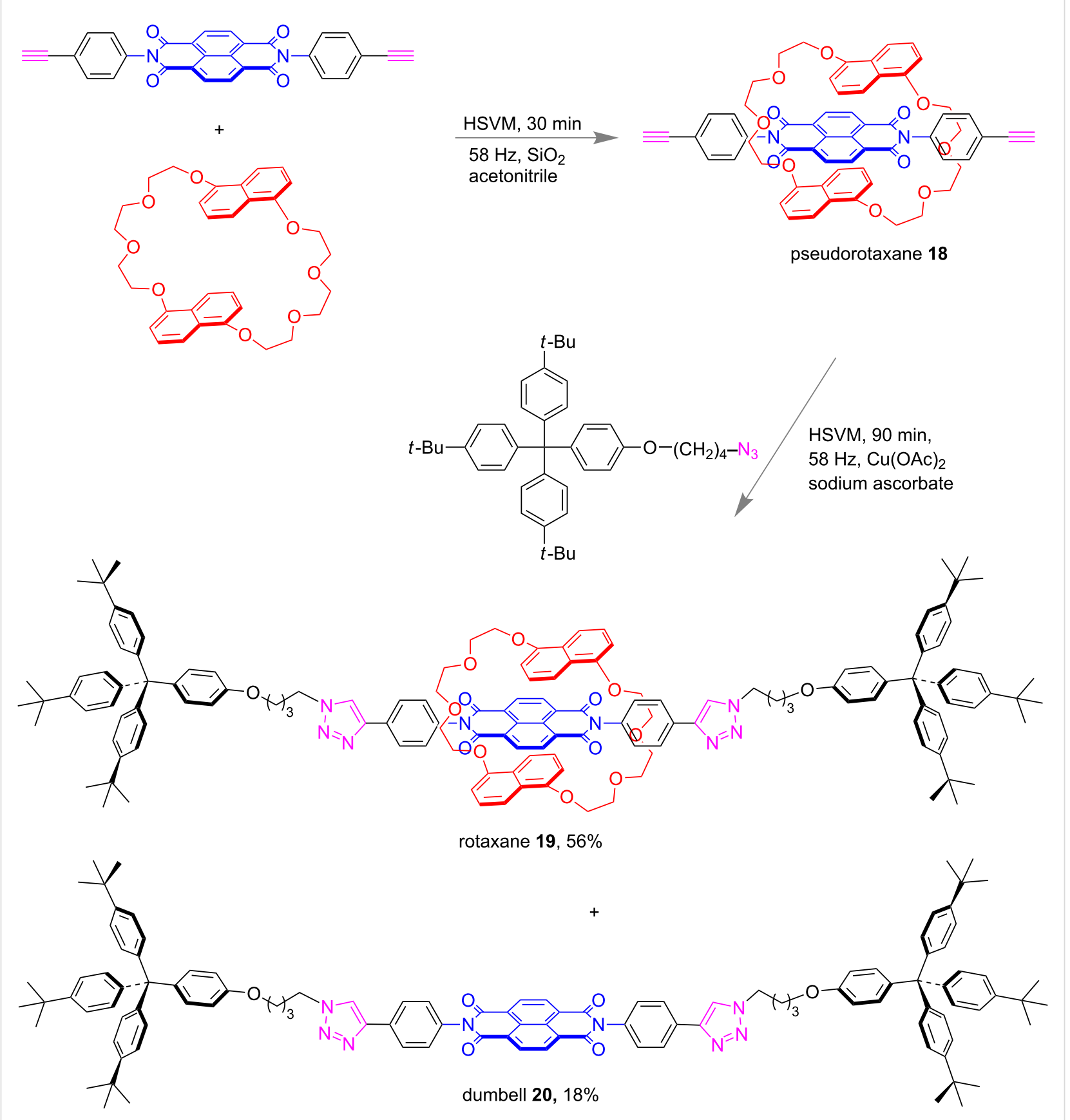

Figure 9: Mechanochemical liquid-assisted one-pot two-step synthesis of [2]rotaxanes under high-speed vibration milling (HSVM) conditions [62].

\section{Subcomponent self-assembly and mechano-milling}

Nature displays innumerable and beautiful creations $[67,68]$ which include highly complex self-assembled structures made from smaller building blocks by using weak or non-covalent interactions $[69,70]$. Therefore, the supramolecular approach [71] and systems chemistry $[1,72]$ are considered as the fastest growing areas of chemical research during the last couple of decades $[73,74]$. The concept of systems chemistry offers a thorough understanding of the building-up principles for creation of complex functional molecular systems from conventional materials $[75,76]$. The systems chemistry approach may give easy access to new structures or functional materials simply by controlling the inputs of a multicomponent system. The concept of self-sorting [77-79] and subcomponent selfassembly approach [80] are well-developed methods being practiced in supramolecular chemistry to produce complex molecules with topological diversity [81]. Therefore, organic trans- 

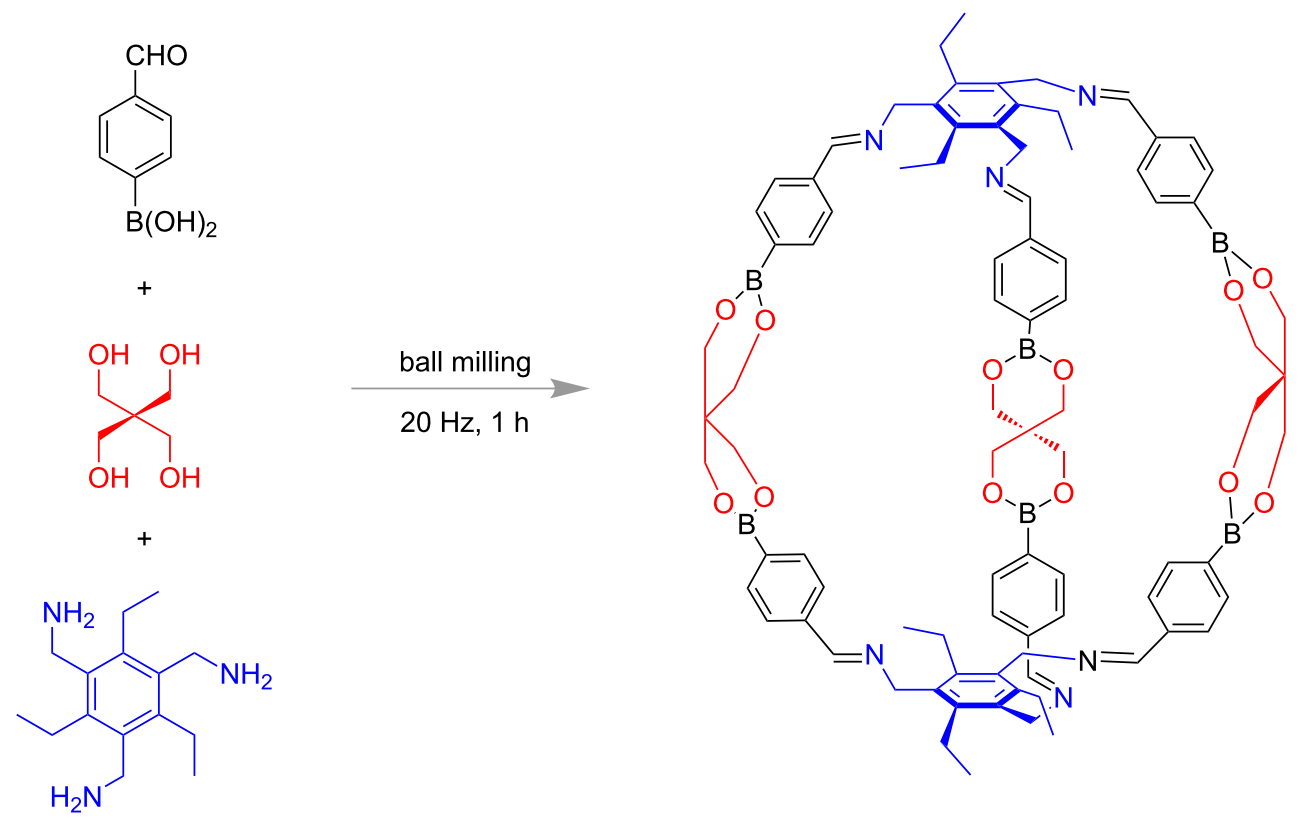

$21,94 \%$

Figure 10: Mechanochemical (ball-milling) synthesis of molecular sphere-like nanostructures [63].<smiles>[R]c1c(Cc2ccc([Se]O)cc2)c([R])c(Cc2ccc([SeH](C)O)cc2)c([R])c1Cc1ccc([Se]O)cc1</smiles>

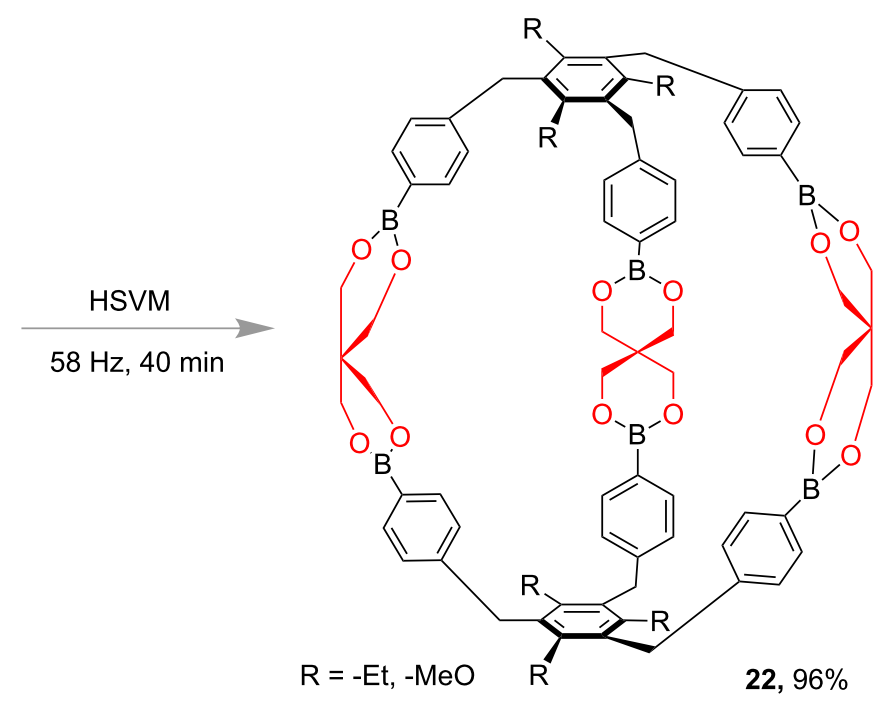

Figure 11: High-speed vibration milling (HSVM) synthesis of boronic ester cages of type 22 [64].

formations through subcomponent synthesis under mechanomilling conditions might be considered as a useful tool for performing a chemical reaction in a greener fashion.

The subcomponent self-assembly of a rigid aromatic linear bisamine, pyridine-2-carboxaldehyde and $\mathrm{Fe}(\mathrm{II})$ resulting in the tetrahedral $\left[\mathrm{M}_{4} \mathrm{~L}_{6}\right]^{4-}$ cage $\mathbf{2 5}$ in water reported by Nitschke [82] was a milestone of supramolecular tetrahedral complex chemistry (Figure 14). The authors have thoroughly explored the host-guest chemistry of that self-assembled Fe(II) cage $[4,12,83]$.

In 2015, Mal's group successfully reproduced the synthesis of Nitschke's tetrahedral iron-cage molecule under solvent-free mechano-milling conditions [84]. Subcomponent self-assembly from components $\mathbf{A}, \mathbf{B}, \mathbf{C}, \mathbf{D}$ and $\mathrm{Fe}(\mathrm{II})$ in a solvent-free environment through self-sorting led to three structurally different metallosupramolecular Fe(II) complexes. Under mechano- 


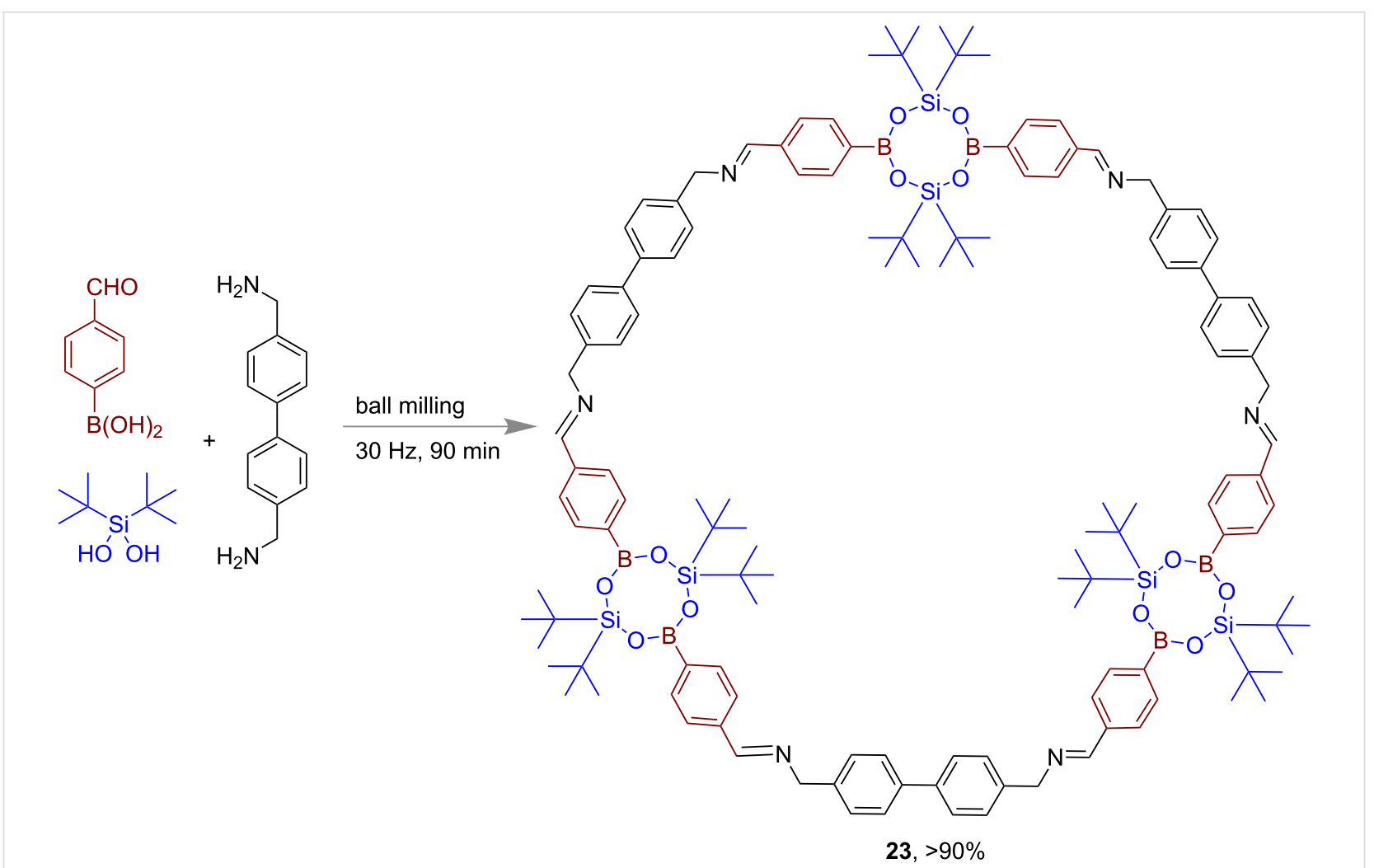

Figure 12: Mechanochemical synthesis of borasiloxane-based macrocycles.

milling conditions the tetranuclear $\left[\mathrm{Fe}_{4}\left(\mathbf{A D}_{2}\right)_{6}\right]^{4-}$ 22-component cage 26, dinuclear $\left[\mathrm{Fe}_{2}\left(\mathbf{B D}_{2}\right)_{3}\right]^{2-} 11$-component selfassembled helicate $\mathbf{2 7}$ and 5-component mononuclear $\left[\mathrm{Fe}\left(\mathbf{C D}_{3}\right)\right]^{2+}$ complex $\mathbf{2 8}$ could be prepared simultaneously in a one-pot reaction starting from 38 components (Figure 15).

In 2015, Mal and co-workers described a multicomponent Biginelli [85] reaction following a subcomponent synthesis under mechanochemical conditions. They have developed a method in which dihydropyrimidone synthesis was achieved from benzyl alcohol using a $\mathrm{Br}^{+}$source as the catalyst (Figure 16). In the reaction pot subcomponents such as benzaldehydes and $\mathrm{H}^{+}$were formed which further participated in a cascade transformation to give dihydropyrimidones $\mathbf{2 9}$.

\section{Dynamic combinatorial chemistry and mechano-milling}

Dynamic combinatorial chemistry (DCC) is one of the most important topics which make us understand the relationship between complex molecules and living systems. With this approach, a library of chemical species called dynamic combinatorial library (DCL) can be designed which are in thermodynamic equilibrium with each other. Nitschke and co-workers reported, that mixing of 2-formylpyridine (3.0 equiv), 6-methyl2 -formylpyridine (3.0 equiv), tris(2-aminoethyl)amine
(1.0 equiv) and ethanolamine (3.0 equiv) in aqueous solution afforded a dynamic library of imines which subsequently could be self-sorted into two distinct complexes $\mathbf{3 0}$ and $\mathbf{3 1}$ upon the addition of $\mathrm{Cu}$ (I) tetrafluoroborate (1.5 equiv) and $\mathrm{Fe}$ (II) sulfate (1.0 equiv) as shown in Figure 17 [86].

DCL formation was also shown to be possible in the solid-state by grinding or mechanochemical methods by Sanders and co-workers in 2011. They have demonstrated the reversibility and thermodynamic control in mechanochemical covalent synthesis, towards base-catalyzed metathesis of aromatic disulfides as a model reaction [87]. The outcome of solution-phase chemistry and mechanochemical synthesis were well distinguished and they have described the phenomenon based on differences in the crystal packing in the solid state. The products $\mathbf{3 2}$ were obtained via thermodynamic control (Figure 18) from a dynamic combinatorial library $[53,88]$.

In 2010, Otto and co-workers observed unprecedented product selectivity for the formation of disulfide macromolecules based on mechanical shaking and stirring [89]. Peptide-chain containing distal thiol groups underwent an aerial oxidation process to give different disulfide-containing macromolecules. They observed that under mechanical shaking conditions preferentially the cyclic hexamer $\mathbf{3 3}$ is formed, whereas stirring resulted in 


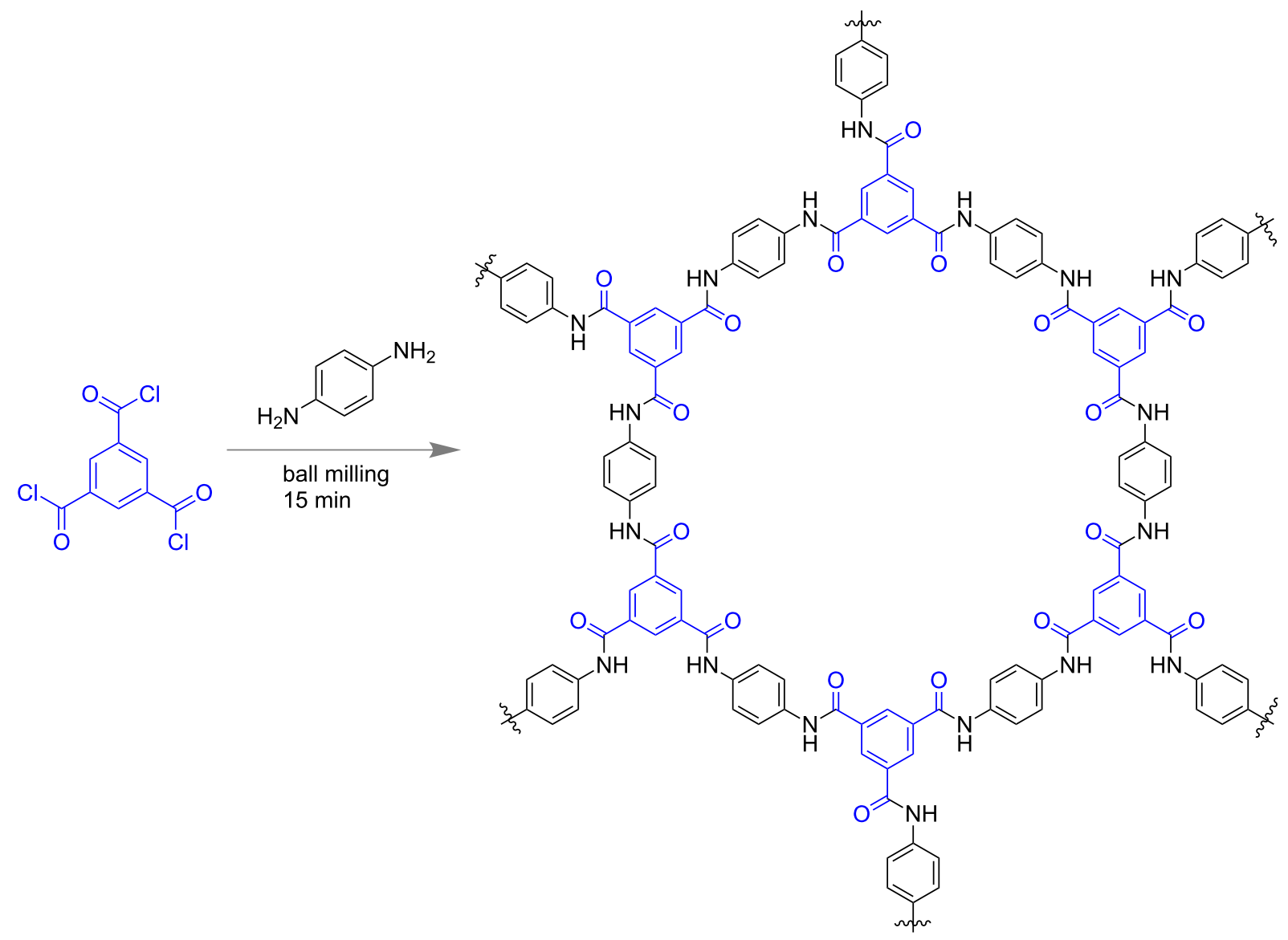

$24,75 \%$

Figure 13: Mechanochemical synthesis of 2-dimensional aromatic polyamides.
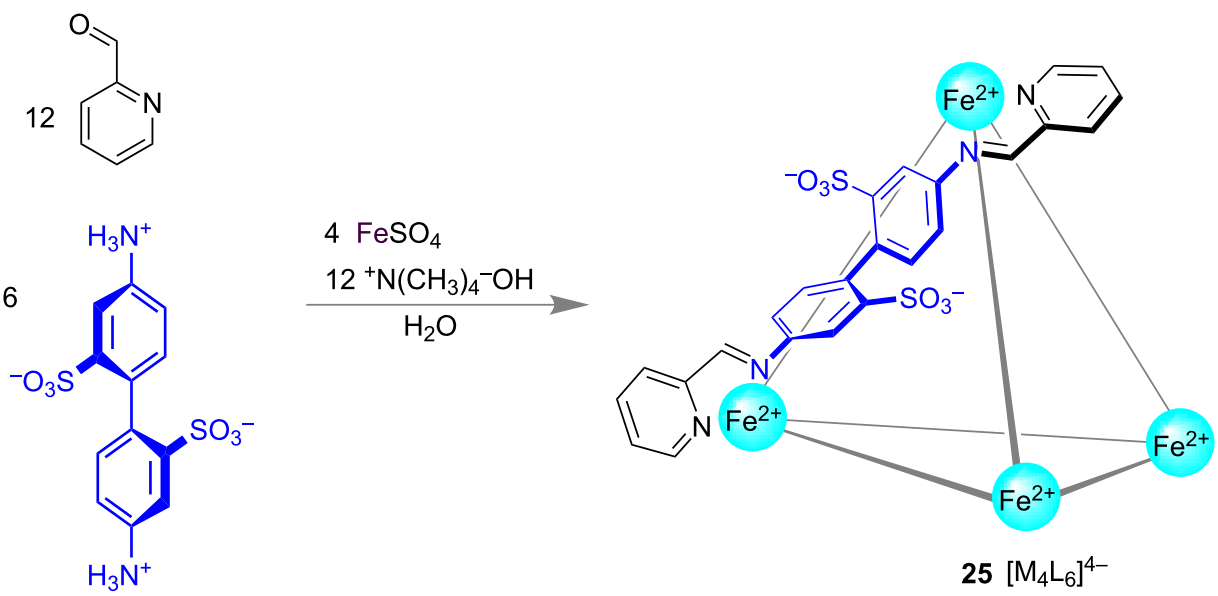

Figure 14: Nitschke's tetrahedral Fe(II) cage 25. 


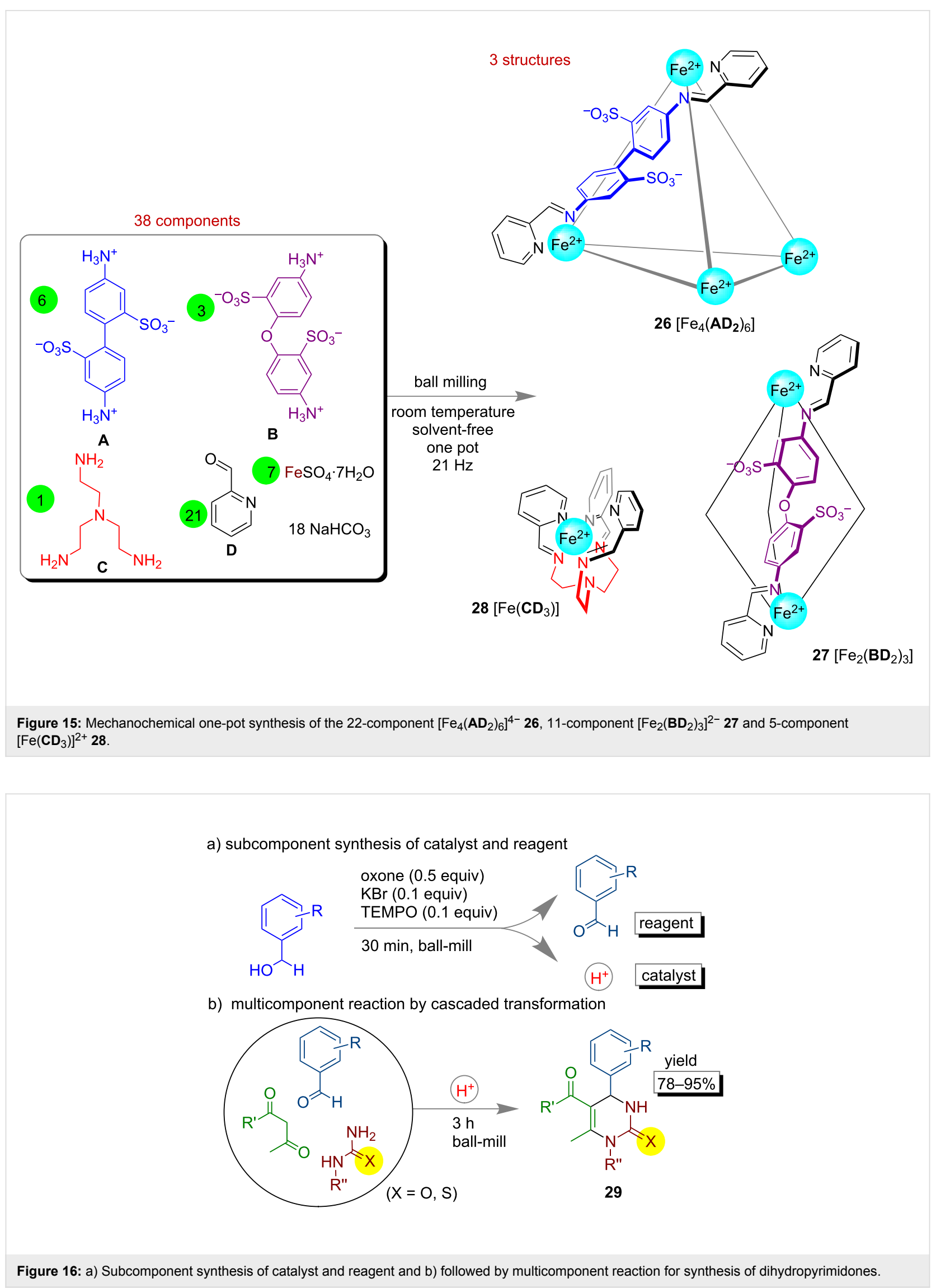


3<smiles>O=Cc1ccccn1</smiles>

3<smiles>Cc1cccc(C=O)n1</smiles><smiles>NCCN1CCNCC1</smiles>

$3 \mathrm{H}_{2} \mathrm{~N} \curvearrowright \mathrm{OH}$

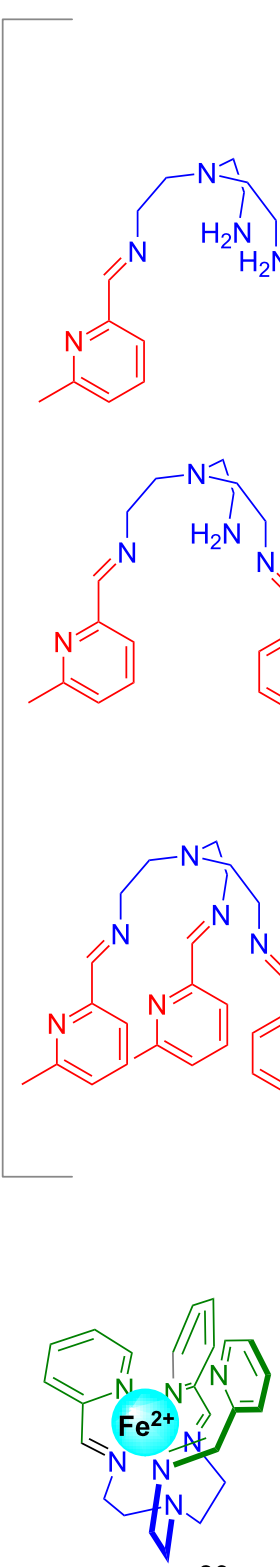

30<smiles>Cc1cccc(/C=N/CCN2CN(N)CCN(Cc3ccccn3)C2)n1</smiles>

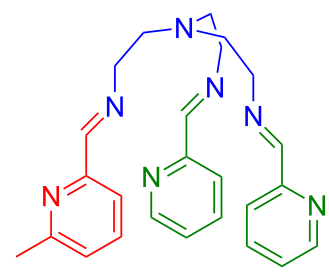<smiles>OCC/N=C/c1ccccn1</smiles><smiles>N=Cc1ccccn1</smiles><smiles>OCCO</smiles>
$\mathrm{H}_{2} \mathrm{~N}$<smiles>C(=NCCN1CC2CCN(CC=NC2)C1c1ccccn1)c1ccccn1</smiles>

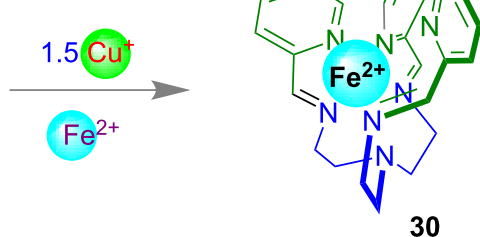

1.5

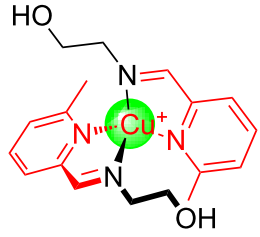

31

Figure 17: A dynamic combinatorial library (DCL) could be self-sorted to two distinct products.

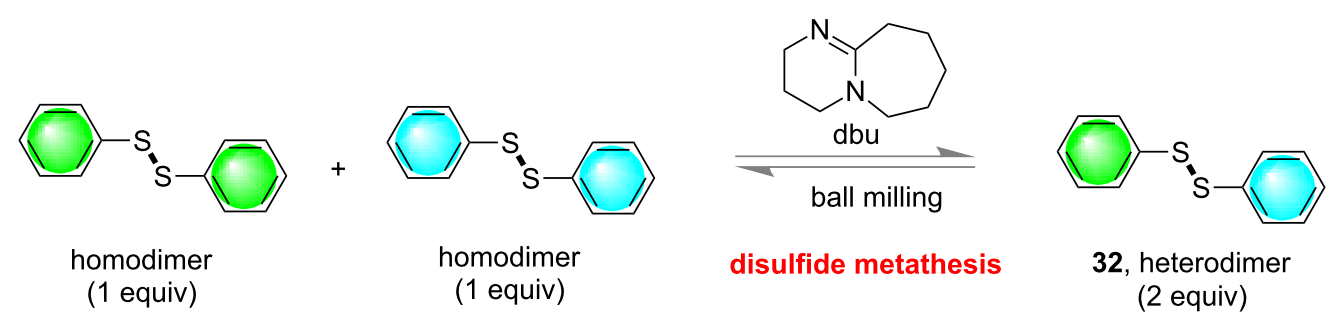

Figure 18: Mechanochemical synthesis of dynamic covalent systems via thermodynamic control. 


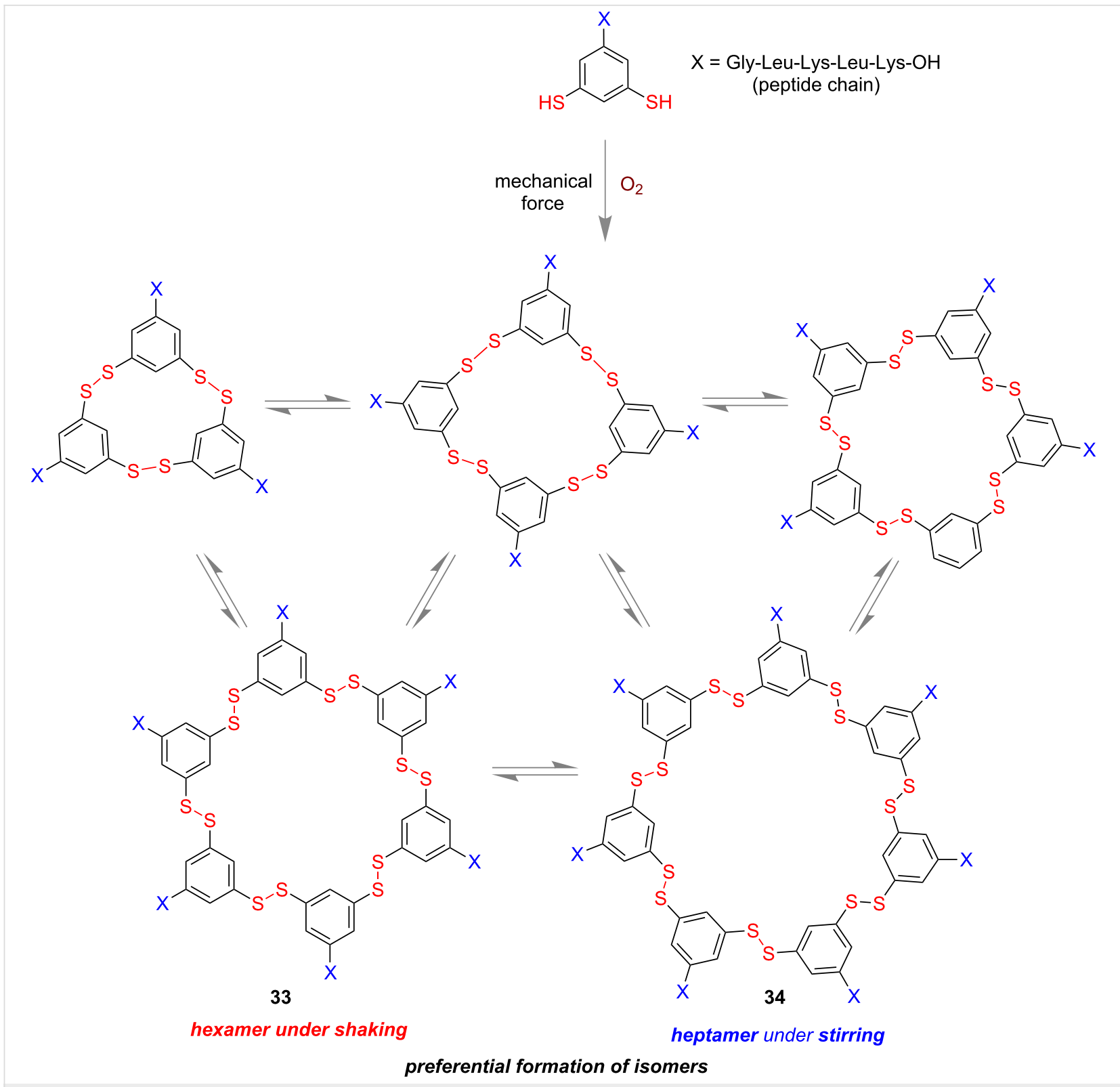

Figure 19: Preferential formation of hexamer 33 under mechanochemical shaking via non-covalent interactions of peptide chains.

formation of heptamer $\mathbf{3 4}$ as the major isomer (Figure 19). From this observation the authors concluded that not only the thermodynamically controlled products but also the kinetically controlled products could be obtained in DCL depending on the non-covalent interactions present in the molecule. Noncovalent interactions of alternating hydrophilic and hydrophobic units in the peptide chains played the vital role in the system.

Friščić and Aav with co-workers reported the first solvent-free mechanochemical synthesis of hemicucurbiturils [90] through the anion template effect of dynamic covalent chemistry $[47,91,92]$. The mechanochemical milling of a 1:1 mixture of paraformaldehyde and $(R, R)$-hexahydro-2-benzimidazolinone along with a small amount of concentrated aqueous $\mathrm{HCl}$ for 30-60 min followed by aging at $45{ }^{\circ} \mathrm{C}$ for 6 days, resulted in the formation of six-membered macrocycle cycHC[6] 35 with 98\% conversion by NMR (Figure 20). When $\mathrm{ClO}_{4}{ }^{-}$has been used as the anion template, the formation of the eight-membered macrocycle cycHC[8] 36 was observed in 98\% conversion by NMR after $30 \mathrm{~min}$ of LAG, followed by aging for one day at $60{ }^{\circ} \mathrm{C}[90]$.

\section{Template-assisted mechanochemistry}

It was long believed that covalent-bond formation in supramolecular chemistry which occurs in solution-phase synthesis is 


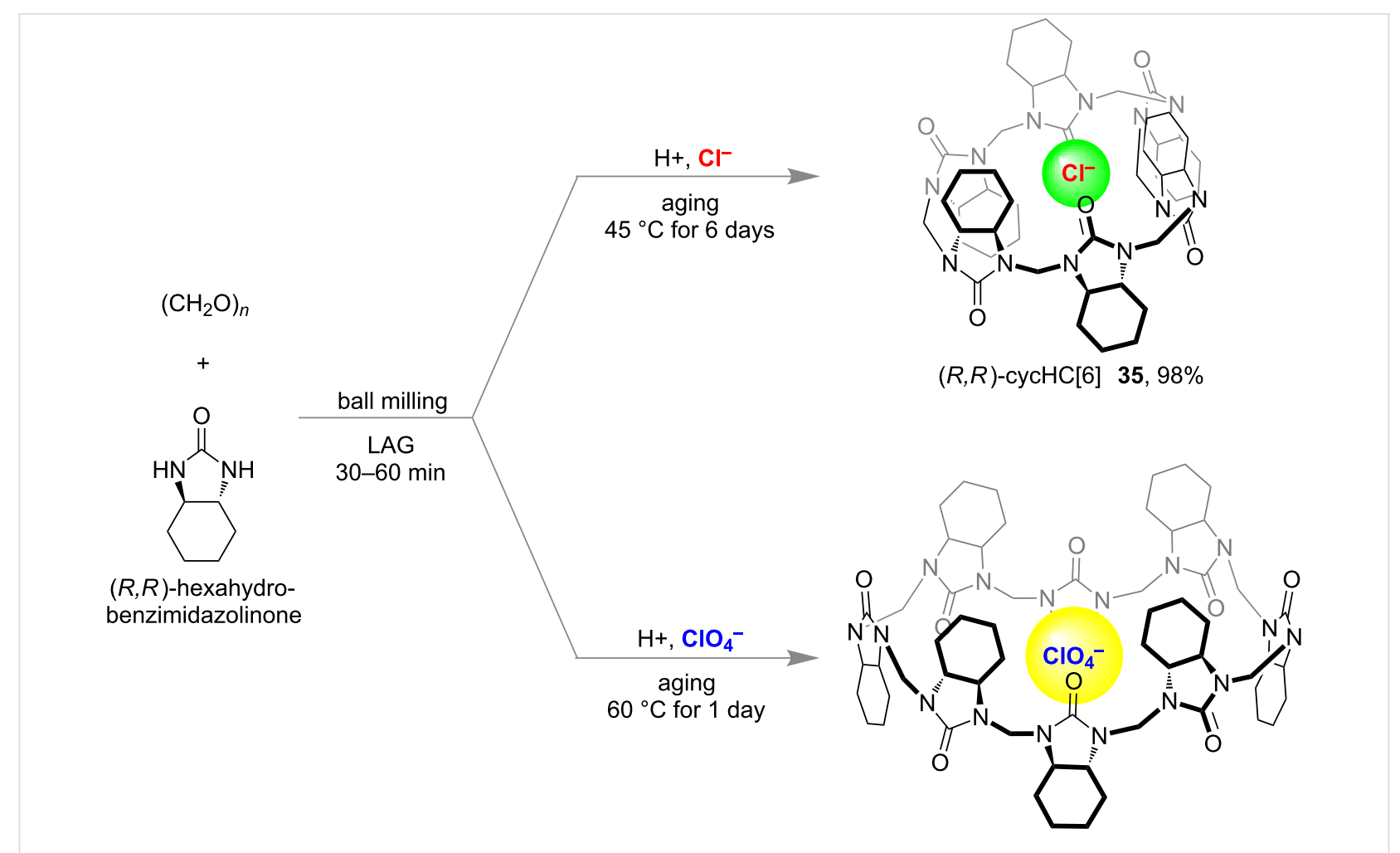

$(R, R)$-cycHC[8] 36, 98\%

Figure 20: Anion templated mechanochemical synthesis of macrocycles cycHC[n] by validating the concept of dynamic covalent chemistry.

almost impossible in solid-state reactions. However, MacGillivray's group demonstrated several examples of co-crystal formation or supramolecular synthesis in the solid phase through mechano-milling or dry grinding. In 2008, they have established a [2+2] photodimerization through solid-state grinding either in neat or liquid-assisted conditions [93]. To achieve $100 \%$ stereospecific products they considered resorcinol derivatives as hydrogen-bond donors for the photodimerization of 1,2-di(pyridin-4-yl)ethylene (Figure 21a). However, 1,8-dipyridylnaphthalene was used as hydrogen-bond acceptor for the $[2+2]$ cycloaddition of fumaric acid derivatives (Figure 21b).

In 2017 Purse and co-workers reported the host-guest chemistry of pyrogallo[4]arene (39) hexamers under mechanomilling conditions [94]. A hexameric capsule $\mathbf{4 0}$ formed through hydrogen-bonding and the cavity was found to be able to encapsulate different organic molecules such as alkanes, acids, amines, etc. The encapsulation of a [2.2]paracyclophane in the cage was achieved by ball milling at $30 \mathrm{~Hz}$ (Figure 22) and the host-guest product $\mathbf{4 0}$ was verified by NMR as well as other spectroscopic techniques.

Georghiou et al. demonstrated the mechanochemical formation of a 1:1 supramolecular complex $\mathrm{C}_{60}$-tert-butylcalix[4]azulene
41 (Figure 23). The host-guest complexation was achieved by simple grinding the individual compounds in a mortar and pestle [95].

\section{Supramolecular catalysis}

The concept of supramolecular catalysis mainly is based on the use of supramolecular chemistry, molecular recognition, host-guest chemistry, etc. for catalysis [96]. The field originated with the understanding of enzymatic system which is conceptually different from traditional organic chemistry reactions, as it relies on soft force $[97,98]$ or non-covalent interactions [2] such as hydrogen bonding [99], cation- $\pi$ [100-102], anion- $\pi$ [103], hydrophobic effect [104,105], halogen bonding [106-109], etc. As enzymes are structurally complex entities and are difficult to modify, supramolecular catalysis proposes a much simpler model to understand the catalytic activity of enzymes.

In 2010, MacGillivray and co-workers have demonstrated the concept of "supramolecular catalysis" in a hydrogen-bondassisted self-assembled formation of a [2+2]-cycloaddition product. The reaction was found to be $100 \%$ stereospecific under dry mortar and pestle grinding [110]. The hydrogen-bond donor 4,6-dichlororesorcinol was used as the supramolecular catalyst for the transformation in the solid-state. From single 
a) resorcinol as hydrogen-bond donor template
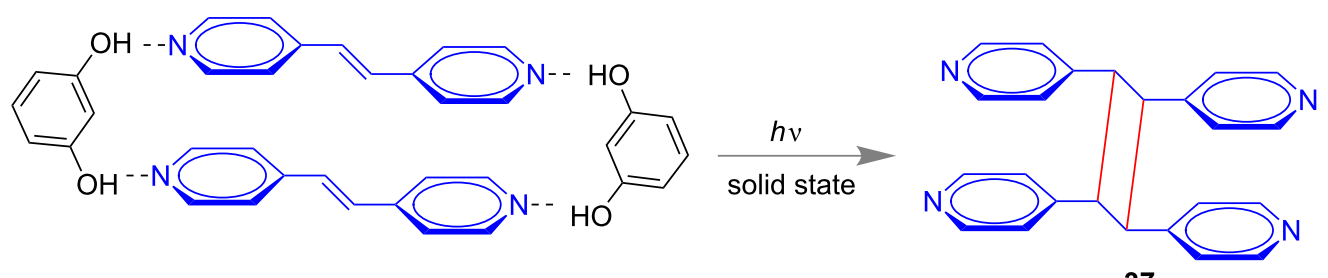

37

b) 1,8-dipyridylnaphthalene as hydrogen-bond acceptor template

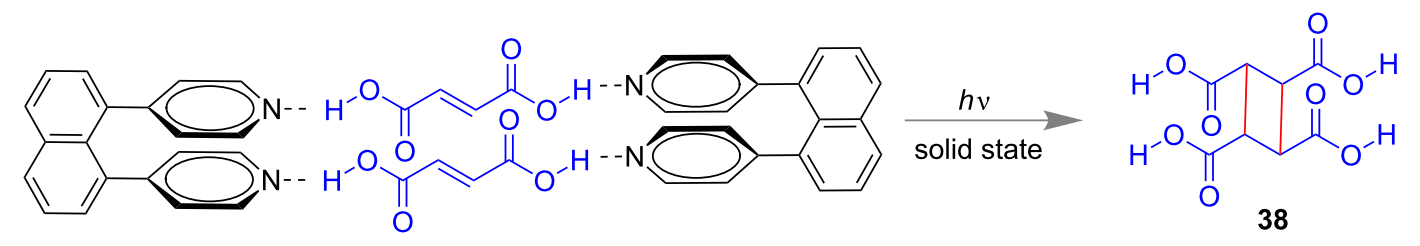

Figure 21: Hydrogen-bond-assisted [2 + 2]-cycloaddition reaction through solid-state grinding. Hydrogen-bond donors are a) resorcinol and b) 1,8-dipyridylnaphthalene, respectively.

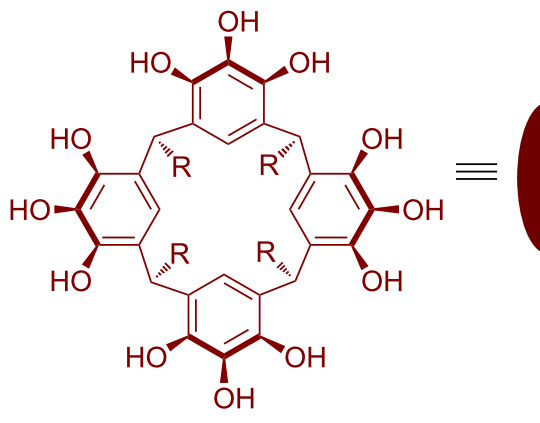

$\mathrm{R}=\mathrm{C}_{10} \mathrm{H}_{21}$

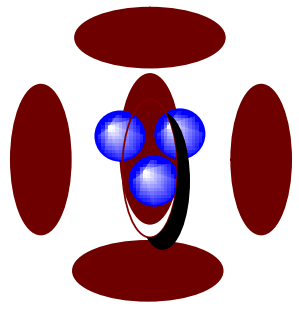

$\mathbf{4 0}=([2.2] \text { paracyclophane })_{3} \cdot 39_{6}$

Figure 22: Formation of the cage and encapsulation of [2.2]paracyclophane guest molecule in the cage was done simultaneously under mechanochemical conditions.<smiles></smiles>

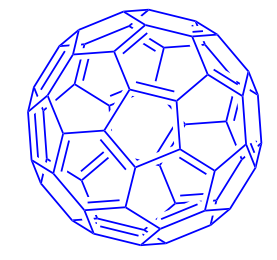

$\mathrm{C}_{60}$

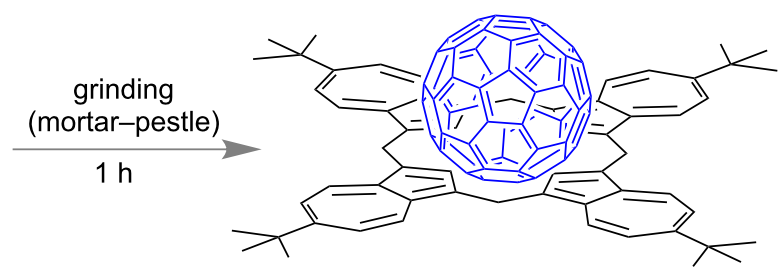

41 (1:1 adduct)

Figure 23: Formation of the 1:1 complex $\mathrm{C}_{60}-$ tert-butylcalix[4]azulene through mortar and pestle grinding of the host and the guest. The structure of the complex was obtained from DFT study. 
crystal X-ray analysis the authors have proved the formation of the 2:2 complex 42 from 1,2-di(pyridin-4-yl)ethylene and 4,6dichlororesorcinol in the transition state (Figure 24). Finally the cyclobutane derivative $\mathbf{4 3}$ was observed after the release of catalyst for the next cycle.

In 2012, again the MacGillivray group reported an improved version of the above mentioned [2 + 2]-cycloaddition methodology. They used the vertex grinding technique where solid-state grinding and UV irradiation was done simultaneously [111] and verified co-crystal formation of a resorcinol derivative with dipyridylethylene in the solid state. Also, the supramolecular catalysis of $[2+2]$ photodimerization has been shown to proceed with excellent turnover numbers.

Recently, Friščić and Cinčić with co-workers reported an elaborative study on the halogen bonding between 1,3,5-trifluoro2,4,6-triiodobenzene and triphenylphosphine, -arsine, and -stibine under neat mechanochemical conditions or through solvent-assisted grinding using ethanol (Figure 25). The single crystal X-ray structures of the obtained co-crystals $44-46$ were reported to match with the solution-phase co-crystals. They have also studied energy levels, thermal properties and the stability of these structures through DFT calculations [112]. In

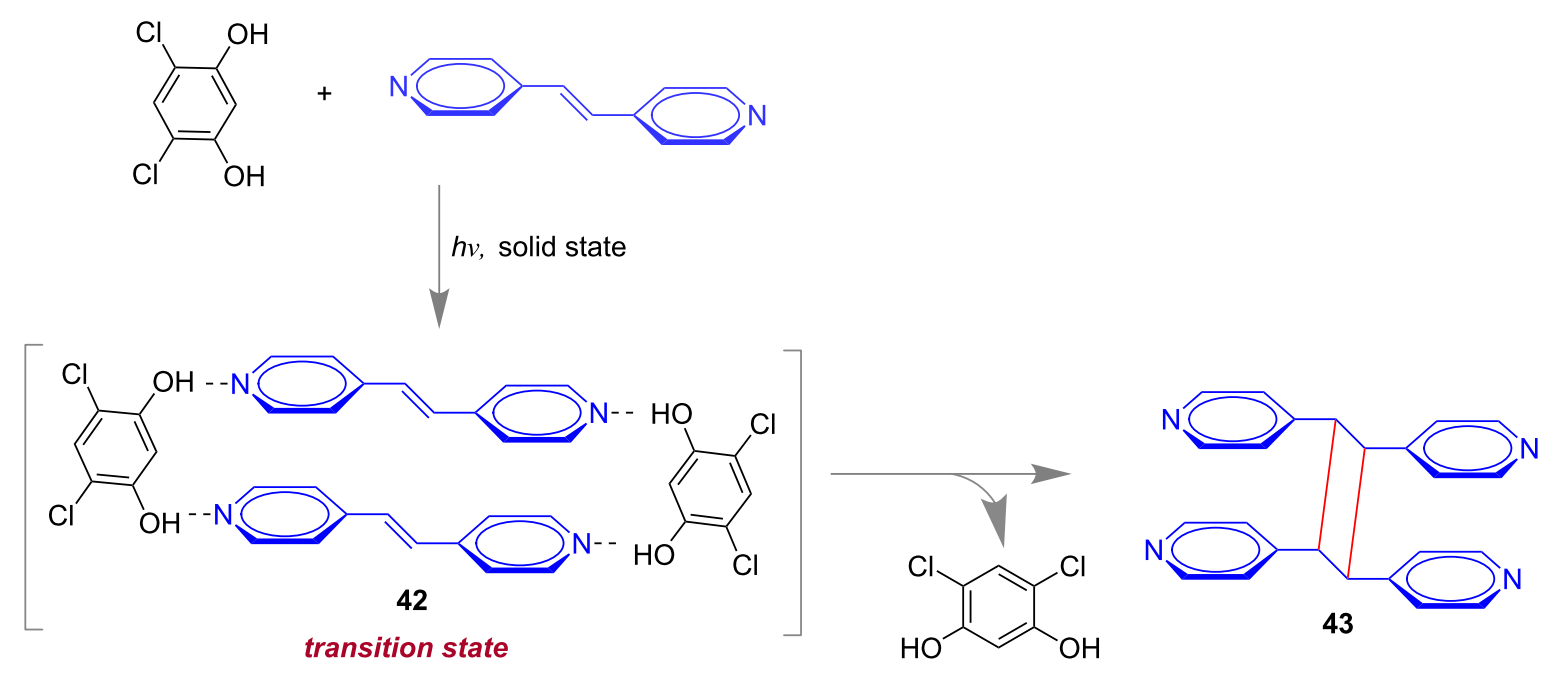

Figure 24: Formation of a 2:2 complex between the supramolecular catalyst and the reagent in the transition state of the [2 +2 ]-cycloaddition reaction of 1,2-di(pyridin-4-yl)ethylene and 4,6-dichlororesorcinol.<smiles>Fc1c(I)c(F)c(I)c(F)c1I</smiles><smiles>Fc1c(I)c(F)c(I(c2ccccc2)c2ccccc2)c(F)c1I</smiles>

\section{halogen-bonded co-crystals}

a)<smiles>CI(C)(C)(c1ccccc1)c1c(F)c(I)c(F)c(I)c1F</smiles>

44 b)<smiles>CI(I)c1c(F)c(I)c(F)c(I)c1F</smiles>

45 c)

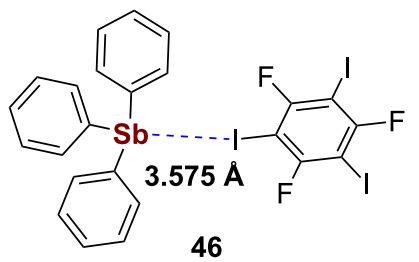

Figure 25: Halogen-bonded co-crystals via a) $\mid \cdots P$, b) $\mid \cdots$ As, and c) $\mid \cdots$ Sb bonds [112] 
this work they have also demonstrated that metallic pnictogens do form sufficiently strong halogen bonds to enable co-crystal formation.

Mal and co-workers have shown that a contact explosive, i.e., the mixture of primary amines and phenyliodine diacetate led to a high-yielding reaction at maximum contact (solvent-free ball milling) of the reactants [113]. An acid salt, (sodium bisulfate) was used to control the reactivity of the highly basic primary amines to transform the exceedingly exothermic reactive substrates in a high-yielding cross-dehydrogenative coupling (CDC) reaction to obtain the amides 47 (Figure 26).

The development of sustainable methods for the activation of less-reactive undirected $\mathrm{C}\left(\mathrm{sp}^{3}\right)-\mathrm{H}$ bonds is challenging however, highly desired in organic synthesis. Mal and co-workers also demonstrated that acidic $\mathrm{C}\left(\mathrm{sp}^{3}\right)$-hydrogen bonds within a mole- cule could be used to control exothermic reactions between amines and iodine(III) [114]. By this process undirected $\mathrm{C}\left(\mathrm{sp}^{3}\right)-\mathrm{H}$ bonds were shown to be functionalized for dehydrogenative imination reactions. Overall, at 1,5-distances (remote) a dehydrogenative and intramolecular $\mathrm{C}\left(\mathrm{sp}^{3}\right)-\mathrm{H}$ imination by $4 \mathrm{H}$ elimination was readily done via organocatalysis using $\mathrm{PhI}$ (10 mol \%)- $m$ CPBA at ambient conditions as well as under neat mixing [115]. The $N^{1}, N^{1}$-dibenzylbenzene-1,2-diamine (Figure 27) which is an integrated system by the combination of aniline and $N, N$-dibenzylaniline led to the successful formation of 1-benzyl-2-phenyl-benzo[d]imidazole $\mathbf{4 8}$ under the iodine(III) environment.

\section{Conclusion}

Over the last years, substantial progress has been made in the area of mechanochemistry as environmentally benign method in organic synthesis, materials science and supramolecular chem-

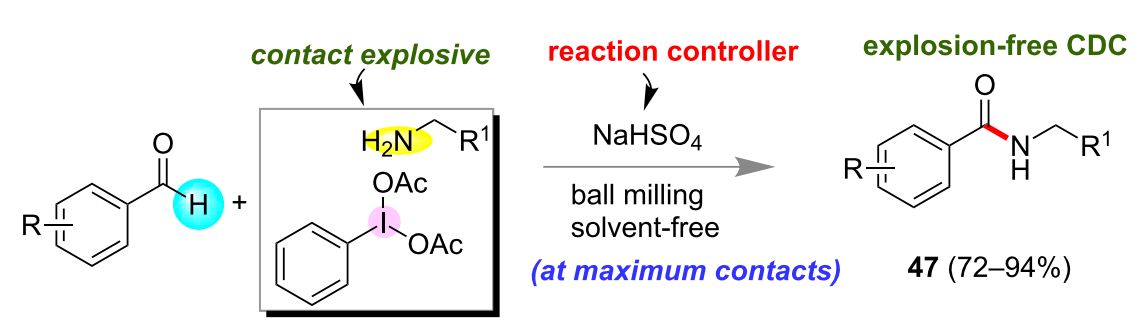

Figure 26: Transformation of contact-explosive primary amines and iodine(III) into a successful chemical reaction for amide synthesis.

a)

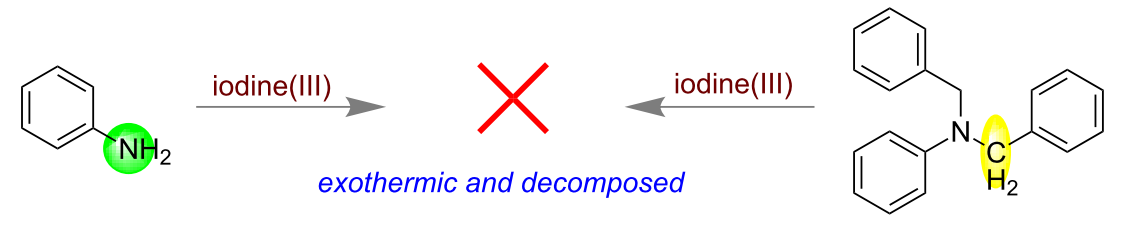

b)<smiles>[R]c1ccccc1CN(Cc1ccccc1)c1ccccc1N</smiles>

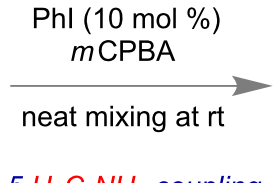

$1,5 \mathrm{H}_{2} \mathrm{C}-\mathrm{NH}_{2}$ coupling

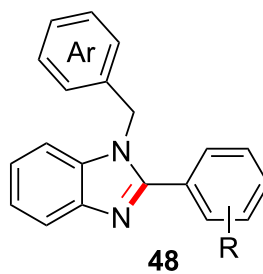

48

c)

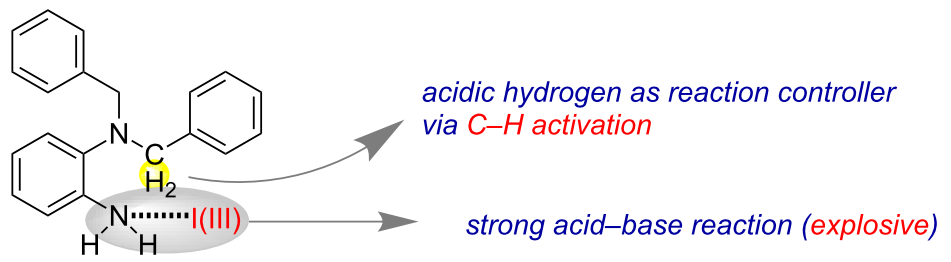

Figure 27: Undirected C-H functionalization by using the acidic hydrogen to control basicity of the amines [114]. a) Identified exothermic reactions. b) Successful reaction by quenching the heat intramolecularly. c) The plausible mechanism of acidic $\mathrm{C}-\mathrm{H}$ functionalization intramolecularly. 
istry. In this review the major focus has been to cover the concept and application of mechanochemistry in the formation of self-assembled supramolecules. In addition, we have included mechanochemical approaches to areas such as subcomponent self-assembly, dynamic combinatorial chemistry, systems chemistry, and supramolecular catalysis. We anticipate that the research area of supramolecular mechanochemistry is still in its infancy and needs significant improvement towards understanding and development of suitable methods [116-118].

\section{Acknowledgements}

A.B. thank CSIR (India) for fellowship.

\section{ORCID ${ }^{\circledR}$ iDs}

Prasenjit Mal - https://orcid.org/0000-0002-7830-9812

\section{References}

1. Ruiz-Mirazo, K.; Briones, C.; de la Escosura, A. Chem. Rev. 2014, 114, 285-366. doi:10.1021/cr2004844

2. Peyralans, J. J.; Otto, S. Curr. Opin. Chem. Biol. 2009, 13, 705-713. doi:10.1016/j.cbpa.2009.08.006

3. Li, J.; Nowak, P.; Otto, S. J. Am. Chem. Soc. 2013, 135, 9222-9239. doi:10.1021/ja402586c

4. Zarra, S.; Wood, D. M.; Roberts, D. A.; Nitschke, J. R. Chem. Soc. Rev. 2015, 44, 419-432. doi:10.1039/c4cs00165f

5. Zhang, G.; Mastalerz, M. Chem. Soc. Rev. 2014, 43, 1934-1947. doi:10.1039/c3cs60358j

6. Wilson, A.; Gasparini, G.; Matile, S. Chem. Soc. Rev. 2014, 43, 1948-1962. doi:10.1039/c3cs60342c

7. Bowman-James, K. Acc. Chem. Res. 2005, 38, 671-678. doi:10.1021/ar040071t

8. Cramer, F. Emil Fischer's Lock-and-Key Hypothesis after 100 years-Towards a Supracellular Chemistry. In Perspectives in Supramolecular Chemistry; Behr, J. P., Ed.; John Wiley \& Sons, Ltd: Chichester, United Kingdom, 2007; pp 1-23. doi:10.1002/9780470511411.ch1

9. Lehn, J.-M. Angew. Chem., Int. Ed. Engl. 1988, 27, 89-112. doi:10.1002/anie.198800891

10. Mahadevi, A. S.; Sastry, G. N. Chem. Rev. 2016, 116, 2775-2825. doi:10.1021/cr500344e

11. Cougnon, F. B. L.; Sanders, J. K. M. Acc. Chem. Res. 2012, 45, 2211-2221. doi:10.1021/ar200240m

12. Zhang, D.; Ronson, T. K.; Nitschke, J. R. Acc. Chem. Res. 2018, 51, 2423-2436. doi:10.1021/acs.accounts.8b00303

13. Percástegui, E. G.; Mosquera, J.; Ronson, T. K.; Plajer, A. J.; Kieffer, M.; Nitschke, J. R. Chem. Sci. 2019, 10, 2006-2018. doi:10.1039/c8sc05085f

14. Haynes, C. J. E.; Zhu, J.; Chimerel, C.; Hernández-Ainsa, S.; Riddell, I. A.; Ronson, T. K.; Keyser, U. F.; Nitschke, J. R. Angew. Chem., Int. Ed. 2017, 56, 15388-15392. doi:10.1002/anie.201709544

15. Miljanić, O. Š. Chem 2017, 2, 502-524. doi:10.1016/j.chempr.2017.03.002

16. Islam, S.; Powner, M. W. Chem 2017, 2, 470-501. doi:10.1016/j.chempr.2017.03.001

17. Ashkenasy, G.; Hermans, T. M.; Otto, S.; Taylor, A. F. Chem. Soc. Rev. 2017, 46, 2543-2554. doi:10.1039/c7cs00117g
18. Mattia, E.; Otto, S. Nat. Nanotechnol. 2015, 10, 111-119. doi:10.1038/nnano.2014.337

19. Schultz, D. M.; Yoon, T. P. Science 2014, 343, 1239176. doi:10.1126/science.1239176

20. Prier, C. K.; Rankic, D. A.; MacMillan, D. W. C. Chem. Rev. 2013, 113, 5322-5363. doi:10.1021/cr300503r

21. de la Hoz, A.; Díaz-Ortiz, Á.; Moreno, A. Chem. Soc. Rev. 2005, 34, 164-178. doi:10.1039/b411438h

22. Toda, F. Acc. Chem. Res. 1995, 28, 480-486. doi:10.1021/ar00060a003

23. Toda, F.; Tanaka, K.; Iwata, S. J. Org. Chem. 1989, 54, 3007-3009. doi:10.1021/jo00274a007

24. Kimura, T. Application of Ultrasound to Organic Synthesis. In Sonochemistry and the Acoustic Bubble; Grieser, F.; Choi, P.-K.; Enomoto, N.; Harada, H.; Okitsu, K.; Yasui, K., Eds.; Elsevier: Amsterdam, Netherlands, 2015; pp 171-186.

25. Baig, R. B. N.; Varma, R. S. Chem. Soc. Rev. 2012, 41, 1559-1584 doi:10.1039/c1cs15204a

26. Varma, R. S. Green Chem. 2014, 16, 2027-2041. doi:10.1039/c3gc42640h

27. Cravotto, G.; Gaudino, E. C.; Cintas, P. Chem. Soc. Rev. 2013, 42, 7521-7534. doi:10.1039/c2cs35456j

28. Braga, D.; Maini, L.; Grepioni, F. Chem. Soc. Rev. 2013, 42 , 7638-7648. doi:10.1039/c3cs60014a

29. James, S. L.; Adams, C. J.; Bolm, C.; Braga, D.; Collier, P.; Friščić, T.; Grepioni, F.; Harris, K. D. M.; Hyett, G.; Jones, W.; Krebs, A.; Mack, J.; Maini, L.; Orpen, A. G.; Parkin, I. P.; Shearouse, W. C.; Steed, J. W.; Waddell, D. C. Chem. Soc. Rev. 2012, 41, 413-447. doi:10.1039/c1cs15171a

30. Ley, S.; O'Brien, M.; Denton, R. Synthesis 2011, 1157-1192. doi:10.1055/s-0030-1259979

31. Achar, T. K.; Maiti, S.; Mal, P. RSC Adv. 2014, 4, 12834-12839. doi:10.1039/c4ra00415a

32. Bose, A.; Mal, P. Tetrahedron Lett. 2014, 55, 2154-2156. doi:10.1016/j.tetlet.2014.02.064

33. Walsh, P. J.; Li, H.; de Parrodi, C. A. Chem. Rev. 2007, 107, 2503-2545. doi:10.1021/cr0509556

34. Beyer, M. K.; Clausen-Schaumann, H. Chem. Rev. 2005, 105, 2921-2948. doi:10.1021/cr030697h

35. Tanaka, K.; Toda, F. Chem. Rev. 2000, 100, 1025-1074. doi:10.1021/cr940089p

36. Wang, G.-W. Chem. Soc. Rev. 2013, 42, 7668-7700. doi:10.1039/c3cs35526h

37. Achar, T. K.; Bose, A.; Mal, P. Beilstein J. Org. Chem. 2017, 13, 1907-1931. doi:10.3762/bjoc.13.186

38. Stolle, A.; Szuppa, T.; Leonhardt, S. E. S.; Ondruschka, B. Chem. Soc. Rev. 2011, 40, 2317-2329. doi:10.1039/c0cs00195c

39. Zhu, S.-E.; Li, F.; Wang, G.-W. Chem. Soc. Rev. 2013, 42, 7535-7570. doi:10.1039/c3cs35494f

40. Tan, D.; Friščić, T. Eur. J. Org. Chem. 2018, 18-33. doi:10.1002/ejoc.201700961

41. Cheng, B.; Cui, S. Top. Curr. Chem. 2015, 369, 97-134. doi:10.1007/128_2015_628

42. Delori, A.; Friščić, T.; Jones, W. CrystEngComm 2012, 14, 2350-2362. doi:10.1039/c2ce06582g

43. Thompson, M. C.; Busch, D. H. J. Am. Chem. Soc. 1964, 86, 3651-3656. doi:10.1021/ja01072a012

44. Thompson, M. C.; Busch, D. H. J. Am. Chem. Soc. 1962, 84, 1762-1763. doi:10.1021/ja00868a073 
45. Leonardi, M.; Villacampa, M.; Menéndez, J. C. Chem. Sci. 2018, 9, 2042-2064. doi:10.1039/c7sc05370c

46. Saha, M. L.; Mittal, N.; Bats, J. W.; Schmittel, M. Chem. Commun. 2014, 50, 12189-12192. doi:10.1039/c4cc05465b

47. Nitschke, J. R. Chem. Soc. Rev. 2014, 43, 1798-1799. doi:10.1039/c4cs90006e

48. Han, M.; Engelhard, D. M.; Clever, G. H. Chem. Soc. Rev. 2014, 43, 1848-1860. doi:10.1039/c3cs60473j

49. Saha, M. L.; Schmittel, M. Org. Biomol. Chem. 2012, 10, 4651-4684. doi:10.1039/c2ob25098e

50. Schmittel, M.; Kalsani, V. Top. Curr. Chem. 2005, 245, 1-53. doi:10.1007/b98165

51. He, Z.; Jiang, W.; Schalley, C. A. Chem. Soc. Rev. 2015, 44, 779-789. doi:10.1039/c4cs00305e

52. Osowska, K.; Miljanić, O. Š. Angew. Chem., Int. Ed. 2011, 50, 8345-8349. doi:10.1002/anie.201102813

53. Ji, Q.; Lirag, R. C.; Miljanić, O. Š. Chem. Soc. Rev. 2014, 43, 1873-1884. doi:10.1039/c3cs60356c

54. Hubin, T. J.; Busch, D. H. Coord. Chem. Rev. 2000, 200-202, 5-52. doi:10.1016/s0010-8545(99)00242-8

55. Ferguson, M.; Giri, N.; Huang, X.; Apperley, D.; James, S. L. Green Chem. 2014, 16, 1374-1382. doi:10.1039/c3gc42141d

56. Orita, A.; Jiang, L.; Nakano, T.; Ma, N.; Otera, J. Chem. Commun. 2002, 1362-1363. doi:10.1039/b203651g

57. Fujita, M.; Yazaki, J.; Ogura, K. J. Am. Chem. Soc. 1990, 112, 5645-5647. doi:10.1021/ja00170a042

58. Juribašić, M.; Užarević, K.; Gracin, D.; Ćurić, M. Chem. Commun. 2014, 50, 10287-10290. doi:10.1039/c4cc04423a

59. Hsueh, S.-Y.; Cheng, K.-W.; Lai, C.-C.; Chiu, S.-H. Angew. Chem., Int. Ed. 2008, 47, 4436-4439. doi:10.1002/anie. 200800530

60. Hsu, C.-C.; Chen, N.-C.; Lai, C.-C.; Liu, Y.-H.; Peng, S.-M.; Chiu, S.-H. Angew. Chem., Int. Ed. 2008, 47, 7475-7478. doi:10.1002/anie.200803056

61. Holler, M.; Stoerkler, T.; Louis, A.; Fischer, F.; Nierengarten, J.-F. Eur. J. Org. Chem. 2019, in press. doi:10.1002/ejoc.201900153

62. Li, H.-G.; Wang, G.-W. J. Org. Chem. 2017, 82, 6341-6348. doi:10.1021/acs.joc.7b00912

63. Icli, B.; Christinat, N.; Tönnemann, J.; Schüttler, C.; Scopelliti, R.; Severin, K. J. Am. Chem. Soc. 2009, 131, 3154-3155. doi:10.1021/ja809279s

64. Hai-Gen, L.; Liang, L.; Hui, X.; Guan-Wu, W. Curr. Org. Chem. 2018, 22, 923-929.

65. Pascu, M.; Ruggi, A.; Scopelliti, R.; Severin, K. Chem. Commun. 2013, 49, 45-47. doi:10.1039/c2cc37538a

66. Yang, Y.; Bu, F.; Liu, J.; Shakir, I.; Xu, Y. Chem. Commun. 2017, 53, 7481-7484. doi:10.1039/c7cc02648j

67. Bruns, C. J.; Stoddart, J. F. The Mechanical Bond: A Work of Art. In Beauty in Chemistry; Fabbrizzi, L., Ed.; Topics in Current Chemistry, Vol. 323; Springer Berlin: Berlin, Germany, 2011; pp 19-72. doi:10.1007/128_2011_296

68. Raymond, K. N.; Brown, C. J. Inner and Outer Beauty. In Beauty in Chemistry; Fabbrizzi, L., Ed.; Topics in Current Chemistry, Vol. 323; Springer: Berlin, Germany, 2012; pp 1-18. doi:10.1007/128_2011_295

69. Mitra, T.; Jelfs, K. E.; Schmidtmann, M.; Ahmed, A.; Chong, S. Y.; Adams, D. J.; Cooper, A. I. Nat. Chem. 2013, 5, 276-281. doi:10.1038/nchem.1550

70. Rotzler, J.; Mayor, M. Chem. Soc. Rev. 2013, 42, 44-62. doi:10.1039/c2cs35217f
71. Chakrabarty, R.; Mukherjee, P. S.; Stang, P. J. Chem. Rev. 2011, 111, 6810-6918. doi:10.1021/cr200077m

72. Giuseppone, N. Acc. Chem. Res. 2012, 45, 2178-2188. doi:10.1021/ar2002655

73. Sun, Q.-F.; Iwasa, J.; Ogawa, D.; Ishido, Y.; Sato, S.; Ozeki, T.; Sei, Y.; Yamaguchi, K.; Fujita, M. Science 2010, 328, 1144-1147. doi:10.1126/science.1188605

74. Ponnuswamy, N.; Cougnon, F. B. L.; Clough, J. M.; Pantos, G. D.; Sanders, J. K. M. Science 2012, 338, 783-785. doi:10.1126/science.1227032

75. Samanta, S. K.; Bats, J. W.; Schmittel, M. Chem. Commun. 2014, 50, 2364-2366. doi:10.1039/c3cc49476d

76. Su, X.; Aprahamian, I. Chem. Soc. Rev. 2014, 43, 1963-1981. doi:10.1039/c3cs60385g

77. Osowska, K.; Miljanić, O. Š. Synlett 2011, 1643-1648. doi:10.1055/s-0030-1260815

78. Ji, Q.; Miljanić, O. Š. J. Org. Chem. 2013, 78, 12710-12716. doi:10.1021/jo402305p

79. Safont-Sempere, M. M.; Fernández, G.; Würthner, F. Chem. Rev. 2011, 111, 5784-5814. doi:10.1021/cr100357h

80. Nitschke, J. R. Acc. Chem. Res. 2007, 40, 103-112. doi:10.1021/ar068185n

81. Kassem, S.; van Leeuwen, T.; Lubbe, A. S.; Wilson, M. R.; Feringa, B. L.; Leigh, D. A. Chem. Soc. Rev. 2017, 46, 2592-2621. doi:10.1039/c7cs00245a

82. Mal, P.; Schultz, D.; Beyeh, K.; Rissanen, K.; Nitschke, J. R. Angew. Chem., Int. Ed. 2008, 47, 8297-8301. doi:10.1002/anie.200803066

83. Mal, P.; Breiner, B.; Rissanen, K.; Nitschke, J. R. Science 2009, 324, 1697-1699. doi:10.1126/science.1175313

84. Giri, C.; Sahoo, P. K.; Puttreddy, R.; Rissanen, K.; Mal, P. Chem. - Eur. J. 2015, 21, 6390-6393. doi:10.1002/chem.201500734

85. Sahoo, P. K.; Bose, A.; Mal, P. Eur. J. Org. Chem. 2015, 6994-6998. doi:10.1002/ejoc.201501039

86. Schultz, D.; Nitschke, J. R. Angew. Chem., Int. Ed. 2006, 45, 2453-2456. doi:10.1002/anie.200504447

87. Belenguer, A. M.; Friščić, T.; Day, G. M.; Sanders, J. K. M. Chem. Sci. 2011, 2, 696-700. doi:10.1039/c0sc00533a

88. Herrmann, A. Chem. Soc. Rev. 2014, 43, 1899-1933. doi:10.1039/c3cs60336a

89. Carnall, J. M. A.; Waudby, C. A.; Belenguer, A. M.; Stuart, M. C. A.; Peyralans, J. J.-P.; Otto, S. Science 2010, 327, 1502-1506. doi:10.1126/science.1182767

90. Kaabel, S.; Stein, R. S.; Fomitšenko, M.; Järving, I.; Friščić, T.; Aav, R. Angew. Chem., Int. Ed. 2019, in press. doi:10.1002/anie.201813431

91. Jin, Y.; Wang, Q.; Taynton, P.; Zhang, W. Acc. Chem. Res. 2014, 47, 1575-1586. doi:10.1021/ar500037v

92. Jin, Y.; Yu, C.; Denman, R. J.; Zhang, W. Chem. Soc. Rev. 2013, 42, 6634-6654. doi:10.1039/c3cs60044k

93. Atkinson, M. B. J.; Bučar, D.-K.; Sokolov, A. N.; Friščić, T.; Robinson, C. N.; Bilal, M. Y.; Sinada, N. G.; Chevannes, A.; MacGillivray, L. R. Chem. Commun. 2008, 5713-5715. doi:10.1039/b812728j

94. Journey, S. N.; Teppang, K. L.; Garcia, C. A.; Brim, S. A.; Onofrei, D.; Addison, J. B.; Holland, G. P.; Purse, B. W. Chem. Sci. 2017, 8, 7737-7745. doi:10.1039/c7sc03821f

95. Georghiou, P. E.; Schneider, C.; Shamov, G.; Lash, T. D.; Rahman, S.; Sabrina Giddings, D. Supramol. Chem. 2016, 28 , 396-402. doi:10.1080/10610278.2015.1108416 
96. Vriezema, D. M.; Comellas Aragonès, M.; Elemans, J. A. A. W.; Cornelissen, J. J. L. M.; Rowan, A. E.; Nolte, R. J. M. Chem. Rev. 2005, 105, 1445-1490. doi:10.1021/cr0300688

97. Maharramov, A. M.; Mahmudov, K. T.; Kopylovich, M. N.; da Silva, M. F. C. G.; Pombeiro, A. J. L. Activation of Covalent Bonds Through Non-covalent Interactions. Non-covalent Interactions in the Synthesis and Design of New Compounds; John Wiley \& Sons, Inc: Hoboken, NJ, 2016; pp 1-21. doi:10.1002/9781119113874.ch1

98. Bose, A.; Maiti, S.; Mal, P. Soft Forces in Organic Synthesis by C-N Coupling Reactions. In Noncovalent Interactions in Catalysis; Mahmudov, K. T.; Kopylovich, M. N.; Guedes da Silva, M. F. C.; Pombeiro, A. J. L., Eds.; Catalysis Series; Royal Society of Chemistry: Cambridge, United Kingdom, 2019; pp 188-208. doi:10.1039/9781788016490-00188

99. Amendola, V.; Fabbrizzi, L.; Mosca, L. Chem. Soc. Rev. 2010, 39, 3889-3915. doi:10.1039/b822552b

100.Dougherty, D. A. Acc. Chem. Res. 2013, 46, 885-893. doi:10.1021/ar300265y

101.Kennedy, C. R.; Lin, S.; Jacobsen, E. N. Angew. Chem., Int. Ed. 2016, 55, 12596-12624. doi:10.1002/anie.201600547

102.Achar, T. K.; Maiti, S.; Mal, P. Org. Biomol. Chem. 2016, 14, 4654-4663. doi:10.1039/c6ob00532b

103. Giese, M.; Albrecht, M.; Rissanen, K. Chem. Rev. 2015, 115 , 8867-8895. doi:10.1021/acs.chemrev.5b00156

104.Li, C.-J. Chem. Rev. 2005, 105, 3095-3166. doi:10.1021/cr030009u

105.Percástegui, E. G.; Mosquera, J.; Nitschke, J. R.

Angew. Chem., Int. Ed. 2017, 56, 9136-9140. doi:10.1002/anie.201705093

106. Breugst, M.; von der Heiden, D.; Schmauck, J. Synthesis 2017, 49, 3224-3236. doi:10.1055/s-0036-1588838

107.Bulfield, D.; Huber, S. M. Chem. - Eur. J. 2016, 22, 14434-14450. doi:10.1002/chem.201601844

108. Cavallo, G.; Metrangolo, P.; Pilati, T.; Resnati, G.; Sansotera, M.; Terraneo, G. Chem. Soc. Rev. 2010, 39, 3772-3783. doi:10.1039/b926232f

109. Turunen, L.; Warzok, U.; Schalley, C. A.; Rissanen, K. Chem 2017, 3, 861-869. doi:10.1016/j.chempr.2017.08.010

110.Sokolov, A. N.; Bučar, D.-K.; Baltrusaitis, J.; Gu, S. X.; MacGillivray, L. R. Angew. Chem., Int. Ed. 2010, 49, 4273-4277. doi:10.1002/anie.201000874

111.Stojaković, J.; Farris, B. S.; MacGillivray, L. R. Chem. Commun. 2012, 48, 7958-7960. doi:10.1039/c2cc33227b

112.Lisac, K.; Topić, F.; Arhangelskis, M.; Cepić, S.; Julien, P. A.; Nickels, C. W.; Morris, A. J.; Friščić, T.; Cinčić, D. Nat. Commun. 2019, 10, 61. doi:10.1038/s41467-018-07957-6

113.Kumar Achar, T.; Mal, P. Adv. Synth. Catal. 2015, 357, 3977-3985. doi:10.1002/adsc.201500914

114.Bose, A.; Maiti, S.; Sau, S.; Mal, P. Chem. Commun. 2019, 55 , 2066-2069. doi:10.1039/c8cc09100e

115. Murarka, S.; Antonchick, A. P. Oxidative Heterocycle Formation Using Hypervalent lodine(III) Reagents. In Hypervalent lodine Chemistry; Wirth, T., Ed.; Topics in Current Chemistry; Springer International Publishing: Cham, Switzerland, 2015; pp 75-104. doi:10.1007/128_2015_647

116. Ribas-Arino, J.; Shiga, M.; Marx, D. Angew. Chem., Int. Ed. 2009, 48, 4190-4193. doi:10.1002/anie.200900673

117.Ribas-Arino, J.; Marx, D. Chem. Rev. 2012, 112, 5412-5487. doi:10.1021/cr200399q
118. Friščić, T.; Halasz, I.; Beldon, P. J.; Belenguer, A. M.; Adams, F.; Kimber, S. A. J.; Honkimäki, V.; Dinnebier, R. E. Nat. Chem. 2013, 5, 66-73. doi:10.1038/nchem.1505

\section{License and Terms}

This is an Open Access article under the terms of the Creative Commons Attribution License (http://creativecommons.org/licenses/by/4.0). Please note that the reuse, redistribution and reproduction in particular requires that the authors and source are credited.

The license is subject to the Beilstein Journal of Organic Chemistry terms and conditions:

(https://www.beilstein-journals.org/bjoc)

The definitive version of this article is the electronic one which can be found at: doi:10.3762/bjoc. 15.86 